\title{
Efficient growth of Kluyveromyces marxianus biomass used as a biocatalyst in the sustainable production of ethyl acetate
}

\author{
Christian Löser $^{1 *}$, Thanet Urit ${ }^{1,2}$, Erik Gruner ${ }^{1}$ and Thomas Bley ${ }^{1}$
}

\begin{abstract}
Background: Whey is just turning from a waste of milk processing to a renewable raw material in biotechnology for producing single-cell protein, bio-ethanol, or ethyl acetate as an economic alternative. Conversion of whey-borne sugar into ethyl acetate requires yeast biomass as a biocatalyst. A high cell concentration results in a quick ester synthesis, but biomass growth means consumption of sugar at the expense of ester production. Efficient and cost-saving biomass production is thus a practical requirement. Whey is poor in nitrogen and has therefore to be supplemented with a bioavailable N source.
\end{abstract}

Methods: Several aerobic growth tests were performed with Kluyveromyces marxianus DSM 5422 as a potent producer of ethyl acetate in whey-borne media supplemented with various $\mathrm{N}$ sources. Preliminary tests were done in shake flasks while detailed studies were performed in a stirred bioreactor.

Results: Ammonium sulfate resulted in strong acidification due to remaining sulfate, but costly pH control increases the salt load, being inhibitory to yeasts and causing environmental impacts. Ammonium carbonate lessened acidification, but its supplement increased the initial pH to 7.5 and delayed growth. Urea as an alternative N source was easily assimilated by the studied yeast and avoided strong acidification (much less base was required for pH control). Urea was assimilated intracellularly rather than hydrolyzed extracellularly by urease. Conversion of urea to ammonium and usage of formed ammonium for biomass production occurred with a similar rate so that the amount of excreted ammonium was small. Ammonium hydroxide as another $\mathrm{N}$ source was successfully added by the $\mathrm{pH}$ controller during the growth of $K$. marxianus DSM 5422, but the medium had to be supplemented with some ammonium sulfate to avoid sulfur limitation and to initiate acidification. Non-limited growth resulted in $82 \mathrm{mg} \mathrm{N}$ per $\mathrm{g}$ of biomass, but $\mathrm{N}$-limited growth diminished the $\mathrm{N}$ content.

Conclusions: K. marxianus could be efficiently produced by supplementing the whey with nitrogen. Urea and ammonia were the favored $\mathrm{N}$ sources due to the proton neutrality at assimilation which lessened the salt load and reduced the supply of alkali for $\mathrm{pH}$ control or made this even needless.

Keywords: Kluyveromyces marxianus; Whey; Growth; Nitrogen; Ammonium; Ammonia; Urea

\footnotetext{
* Correspondence: christian.loeser@tu-dresden.de

${ }^{1}$ Institute of Food Technology and Bioprocess Engineering, TU Dresden,

01062 Dresden, Germany

Full list of author information is available at the end of the article
} 


\section{Background}

Sustainable and environmentally compatible development requires successive substitution of fossil resources by renewable raw materials. This applies to the energy sector but is also true for production of industrial bulk materials. Such a bulk chemical is ethyl acetate with an annual world production of 1.7 million tons [1]. Ethyl acetate is an organic solvent of moderate polarity with versatile industrial applications. Another prospective application is the biodiesel production from vegetable oil; here, triglycerides are transformed to fatty acid ethyl esters in a lipase-catalyzed transesterification reaction with ethyl acetate as an acyl acceptor instead of methanol [2-5]. Although being an irritant and intoxicant at higher concentrations, ethyl acetate is less toxic to humans compared to many other solvents. Ethyl acetate is an environmentally friendly compound since the ester is easily degraded by bacteria [6-8] and is regarded as a non-persistent pollutant of the atmosphere [9].

Synthesis of ethyl acetate currently proceeds by petrochemical processes, which are based on crude oil constituents or natural gas, run at elevated temperature and pressure and commonly require catalysts [9]. The reactions are often incomplete, and the recovery of ethyl acetate and residual precursors needs a high input of energy.

Microbial production of ethyl acetate from renewables could become an interesting alternative. Various yeast species can synthesize ethyl acetate (reviewed by Löser et al. [9]), but only Pichia anomala, Candida utilis, and Kluyveromyces marxianus produce this ester in larger amounts. $K$. marxianus is the most promising candidate for large-scale ester production since this dairy yeast with GRAS status grows quickly, converts sugar directly into ethyl acetate without ethanol as an essential intermediate, and produces the ester with a high rate and yield [9-17]. The ester synthesis in $K$. marxianus is easy to control by the level of iron [11,13,16-18]. K. marxianus exhibits a distinct thermal tolerance which allows cultivation at an elevated temperature $[14,19,20]$ which in turn accelerates the ester stripping and advances its process-integrated recovery. The outstanding capability of $K$. marxianus for lactose utilization offers the chance for using whey as a resource of ester synthesis. K. marxianus converts whey-borne lactose with a high yield into ethyl acetate [9], but its ability for sucrose and glucose assimilation [19-21] enables production of ethyl acetate with this yeast from renewables like sugarcane, grain, and corn.

Ethanol is another product of microbial sugar conversion, but several factors favor microbial ester over ethanol production [22]: the higher market price of the ester, a reduced number of process stages, a faster process, and a cost-saving product recovery.

Conversion of sugar into ethyl acetate requires yeast biomass as a biocatalyst. A high biomass concentration results in a quick process, but the production of this biomass, on the other hand, is connected with sugar consumption which reduces the portion of sugar available for ester production (as demonstrated in pilot-scale experiments [13]). The right balance between yeast growth and ester synthesis or, in other words, a compromise between a quick process and a high ester yield is of practical importance. This balance can be controlled by the available iron $[13,16,23]$.

An efficient production of the required yeast biomass is an important factor for the economy of the total process of ester and ethanol production. At whey-based bio-ethanol production, the biomass is often considered as a gift and sugar utilization for biomass production is ignored. Such an 'out-sourcing' of biomass processing only seemingly improves the economy.

Much research was done in the field of whey-based $K$. marxianus cultivation for single-cell protein production [24-28]. The results refer to some problems at cultivation of $K$. marxianus in whey-based media; whey is poor in bioavailable nitrogen so that nitrogen can limit yeast growth [26-29]. Nitrogen-limited growth can even deregulate yeast metabolism and provoke ethanol formation at aerobic conditions [30].

Whey was often supplemented with ammonium as a source of nitrogen to stimulate growth of $K$. marxianus [10-14,16,27,29,31-37]. Added ammonium increased the yield of biomass $[27,32,35]$ or was without significant effect $[29,31,36]$. Ammonium is usually supplemented in the form of ammonium sulfate where ammonium is intensively consumed while most of the sulfate remains in the medium and causes an ionic imbalance and acidification [15,38-41]. Such acidification can be inhibitory to $K$. marxianus since its growth rate is distinctly reduced at $\mathrm{pH} \leq 3.5[22,28,42,43]$. Supplementation of whey with $\left(\mathrm{NH}_{4}\right)_{2} \mathrm{SO}_{4}$ or $\mathrm{NH}_{4} \mathrm{Cl}$ requires cost-intensive $\mathrm{pH}$ correction with $\mathrm{NaOH}$ or $\mathrm{KOH}$ which in turn increases the salt load and thus inhibits yeast growth $[31,42]$ and creates waste-water problems.

Urea is an alternative $\mathrm{N}$ source since growth with urea exhibits proton neutrality without significant $\mathrm{pH}$ changes [38-40]. Assimilation of urea by yeasts is not an exception but the rule; 122 of 123 tested yeasts were able to metabolize urea [44]. There are several potential advantages of urea [25,28,39]: a high amount of nitrogen per unit weight, a low price, and a reduced or even omitted supply of $\mathrm{pH}$ correctives. K. marxianus definitely metabolizes urea, and whey was repeatedly supplemented with urea as an $\mathrm{N}$ source for this yeast [28,31,32,37,45-47]. However, the effect of added urea on growth was often not described $[37,45,46]$, or the published results were contradictory. Yadav et al. [28] observed an increased biomass yield, Kar and Misra [32] found no positive effect, Mahmoud and Kosikowski [31] described slight inhibition by added urea, and Rech et al. [47] even detected strong 
inhibition of growth which had been attributed to alkalinization. These inconsistent results require clarification by more detailed studies on this subject.

The first objective of this work was testing the effect of $\left(\mathrm{NH}_{4}\right)_{2} \mathrm{SO}_{4},\left(\mathrm{NH}_{4}\right)_{2} \mathrm{CO}_{3}$, or urea as sources of nitrogen at aerobic growth of $K$. marxianus DSM 5422 in whey-borne medium with special attention on yeast growth and acidification. When using $\left(\mathrm{NH}_{4}\right)_{2} \mathrm{SO}_{4}$, sulfate remains in the medium and causes proton imbalance and acidification but, when using $\left(\mathrm{NH}_{4}\right)_{2} \mathrm{CO}_{3}$, carbonate disappears in form of $\mathrm{CO}_{2}$ during cultivation which possibly avoids acidification. The second objective was studying the growth of $K$. marxianus DSM 5422 in whey-borne medium with urea in detail at defined conditions to get a deeper insight into the urea metabolism. The third objective was testing the $\mathrm{pH}$-controlled feed of ammonia during aerobic growth of $K$. marxianus DSM 5422 in whey-borne medium. Ammonia as the cheapest source of nitrogen is interesting for large-scale processes.

\section{Methods \\ Microorganism}

K. marxianus DSM 5422 from the Deutsche Sammlung von Mikroorganismen und Zellkulturen GmbH (Braunschweig, Germany) was maintained with the Cryoinstant preservation system (Lomb Scientific Pty Ltd, Vienna, Austria), cultivated on yeast-glucose-chloramphenicol agar (Roth $\mathrm{GmbH}$, Karlsruhe, Germany) for 2 days at $32^{\circ} \mathrm{C}$, and then used as an inoculum.

\section{Non-supplemented DW medium}

All media originate from concentrated and partially demineralized sweet whey. Sweet whey was ultrafiltrated, concentrated by reverse osmosis, and then demineralized by slight alkalinization and moderate heating to yield the used whey permeate (thus processed in the Sachsenmilch Leppersdorf $\mathrm{GmbH}$, Leppersdorf, Germany). Non-supplemented DW medium was prepared in batches of $1 \mathrm{~L}$ by mixing $0.5 \mathrm{~L}$ whey permeate with the same volume water. This mixture was autoclaved in a sealed 1-L Schott bottle for $15 \mathrm{~min}$ at $121^{\circ} \mathrm{C}$. Precipitated minerals were allowed to settle overnight before the upper phase was withdrawn for cultivation experiments. Nonsupplemented DW medium should not be confused with DW basic medium (as used in $[11-14,16]$ ) which contains $10 \mathrm{~g} / \mathrm{L}\left(\mathrm{NH}_{4}\right)_{2} \mathrm{SO}_{4}$.

\section{Shake-flask cultivation}

In a first series of shake-flask experiments, various media were prepared like the just-described non-supplemented DW medium with the modification that various sources of nitrogen $\left(10 \mathrm{~g} / \mathrm{L}\left(\mathrm{NH}_{4}\right)_{2} \mathrm{SO}_{4}, 10 \mathrm{~g} / \mathrm{L}\left(\mathrm{NH}_{4}\right)_{2} \mathrm{CO}_{3}\right.$, or $5 \mathrm{~g} / \mathrm{L}$ urea) were added before medium sterilization. The media handling (autoclaving, settlement, withdrawal) occurred as in the above-described manner. These media were supplemented with $2 \mathrm{~mL} / \mathrm{L}$ autoclaved trace-element solution (preparation as described in [10]) and diluted with water to $1 / 20$ for reducing the content of sugar to $3.9 \mathrm{~g} / \mathrm{L}$ and, thus, to avoid oxygen-limited growth at a low oxygentransfer rate in shake flasks. Several $500-\mathrm{mL}$ conical flasks with cotton plugs were filled each with $50 \mathrm{~mL}$ medium, inoculated with an agar-plate culture as described in [14], and shaken with $250 \mathrm{rpm}$ at $32^{\circ} \mathrm{C}$. After $14 \mathrm{~h}$ of precultivation, the process was followed by regular analysis of the optical density (OD) and the $\mathrm{pH}$ value over a period of at least $10 \mathrm{~h}$. After a total of $40 \mathrm{~h}$ of cultivation, the OD and $\mathrm{pH}$ were measured and the residual sugar and formed biomass were analyzed.

A second series of shake-flask experiments was based on autoclaved non-supplemented DW medium. Portions of this medium were supplemented with $2 \mathrm{~mL} / \mathrm{L}$ sterile trace-element solution and separately autoclaved aqueous stock solutions of $\left(\mathrm{NH}_{4}\right)_{2} \mathrm{SO}_{4},\left(\mathrm{NH}_{4}\right)_{2} \mathrm{CO}_{3}$, or urea. The $\mathrm{pH}$ was then adjusted to 6.5 with $0.1 \mathrm{M} \mathrm{HCl}$ or $\mathrm{KOH}$. These media were diluted with water to reduce the sugar content to $3.9 \mathrm{~g} / \mathrm{L}$ like in the first series. Discrete sterilization of whey and $\mathrm{N}$ sources in this second series avoided unwanted interaction between whey constituents and $\mathrm{N}$ compounds such as the Maillard reaction. Inoculation, cultivation, and analyses occurred as in the first series.

\section{Bioreactor cultivation}

One reference experiment was done with DW basic medium (DW medium with $\left.10 \mathrm{~g} / \mathrm{L}\left(\mathrm{NH}_{4}\right)_{2} \mathrm{SO}_{4}\right)$ and described in detail in [11] while all other presented bioreactor processes were based on non-supplemented DW medium. The sterile 1-L stirred bioreactor with $0.6 \mathrm{~mL}$ Antifoam A (Fluka, Sigma Aldrich, St. Louis, USA) was filled with $0.6 \mathrm{~L} \mathrm{DW}$ medium and $1.2 \mathrm{~mL}$ trace-element solution (the latter described in [10]). Further supplements such as $\left(\mathrm{NH}_{4}\right)_{2} \mathrm{SO}_{4}$, urea, and $\mathrm{Na}_{2} \mathrm{SO}_{4}$ were put into 100$\mathrm{mL}$ Schott bottles, autoclaved for $15 \mathrm{~min}$ at $121^{\circ} \mathrm{C}$, and then transferred to the bioreactor as follows: the bottle was connected with the bioreactor, some culture medium was pumped to the bottle, and, after complete dissolution of the substance, transported back to the reactor. Separate autoclaving avoided unwanted interaction such as the Maillard reaction and sulfate precipitation.

The cultivation occurred as usual [10-12,14]: the medium was inoculated with five loops of biomass, and the reactor was operated at $1,200 \mathrm{rpm}$ and $32^{\circ} \mathrm{C}$ and gassed with $50 \mathrm{~L} / \mathrm{h}$ dry and $\mathrm{CO}_{2}$-free air (given for $0^{\circ} \mathrm{C}$ and $101,325 \mathrm{~Pa}$ ). The $\mathrm{pH}$ was controlled to $\geq 5$ with $2 \mathrm{M}$ $\mathrm{KOH}$ or $2 \mathrm{M}$ ammonia solution. All processes lasted at least $36 \mathrm{~h}$. Sampling and sample preparation were performed as usual [10]. 


\section{Test for urea assimilation}

K. marxianus DSM 5422 was cultivated in diluted DW medium with urea (3.9 g/L sugars, $0.25 \mathrm{~g} / \mathrm{L}$ urea) as described for the second series of shake-flask experiments. After depletion of the sugar, the cell suspension was separated into biomass and supernatant by centrifugation. The biomass was suspended in 50-mM phosphate buffer at $\mathrm{pH} 6$ containing $0.25 \mathrm{~g} / \mathrm{L}$ urea to yield an initial biomass concentration of $2 \mathrm{~g} / \mathrm{L}$, and the supernatant was supplemented with urea to give a concentration of $0.25 \mathrm{~g} / \mathrm{L}$. Both mixtures were then shaken with $250 \mathrm{rpm}$ at $32^{\circ} \mathrm{C}$. Sampling occurred at the beginning and after $24 \mathrm{~h}$ of incubation. The samples were analyzed regarding urea and ammonium.

\section{Analyses}

The optical density of cell suspensions was measured photometrically at $600 \mathrm{~nm}$ (after pre-dilution to OD $<0.4$ if required). The biomass dry weight was determined by separating the yeasts via centrifugation, washing the pellet twice, and drying at $103^{\circ} \mathrm{C}$. Sugar was quantified by a modified 3,5-dinitrosalicylic-acid method [48] with lactose as a standard. Ammonium, nitrate, nitrite, sulfate, and phosphate were measured by the LCK303, LCK339, LCK342, LCK153, and LCK049 cuvette tests (Hach Lange GmbH, Düsseldorf, Germany). The total dissolved nitrogen was analyzed by the Kjeldahl method (German DIN 38409 H11). Ethanol was quantified by gas chromatography [10].

Urea was measured in the style of Rahmatullah and Boyde [49] with some modifications. This method had been approved for quantifying urea in wine [50] being a matrix similar to culture liquids. Two reagents were prepared: a mixture of $300 \mathrm{~mL}$ sulfuric acid (95\% to 98\%, $\rho=$ $1,840 \mathrm{~g} / \mathrm{L}), 100 \mathrm{~mL}$ phosphoric acid (85\%, $\rho=1,670 \mathrm{~g} / \mathrm{L})$, and $100 \mathrm{~mL}$ water; and a solution of $500 \mathrm{mg}$ butane-2,3dione monoxime (diacetyl monoxime) and $10 \mathrm{mg}$ thiosemicarbazide in $100 \mathrm{~mL}$ water. The analysis reagent was prepared from $40 \mathrm{~mL}$ acid mixture and $20 \mathrm{~mL}$ of the second solution and used immediately. A volume of $0.1 \mathrm{~mL}$ sample was mixed with $3 \mathrm{~mL}$ analysis reagent. In the case of colored samples, this mixture was measured photometrically at $525 \mathrm{~nm}$ as a blind. Then, the mixture was put in a 25-mL test tube with plastic cap and incubated for $20 \mathrm{~min}$ in boiling water. After cooling and short mixing, the absorbance was measured at $525 \mathrm{~nm}$. The blind was subtracted, and the obtained $\Delta \mathrm{A}_{525 \mathrm{~nm}}$ value was interpreted as a urea concentration by a non-linear calibration curve prepared for several solutions of urea in water (from 0 to $500 \mathrm{mg} / \mathrm{L}): C_{\text {Urea, } \mathrm{L}}=a \cdot\left(\Delta \mathrm{A}_{525 \mathrm{~nm}}\right)^{b}$ with $a=520 \mathrm{mg} / \mathrm{L}$ and $b=1.37$.

\section{Data analyses}

The $\mathrm{O}_{2}$ consumption, $\mathrm{CO}_{2}$ formation, and the respiratory quotient (RQ) were calculated as usual [11]. The time-dependent specific growth rate was calculated from masses of formed $\mathrm{CO}_{2}$ assuming a correlation between yeast growth and $\mathrm{CO}_{2}$ formation which only applies to respiratory processes without significant maintenance: $\mu(t) \approx$ $\Delta \ln \left(m_{\mathrm{CO} 2}(t)\right) / \Delta t$. The overall biomass yield $\left(Y_{\mathrm{X} / \mathrm{S}}\right)$ is the ratio between the mass of yeasts grown and the mass of sugar consumed; determination of these masses took losses by sampling and changes of the liquid volume into account. The $\mathrm{pH}$-controlled feeding of $2 \mathrm{M} \mathrm{KOH}$ is given as a specific volume, related to the initial liquid volume of the culture. The mass of fed $\mathrm{KOH}$ was related to the formed biomass (given as $\mathrm{g}_{\mathrm{KOH}} / \mathrm{g}_{\mathrm{X}}$ ). The fed $2 \mathrm{M}$ ammonia solution is also expressed as a specific volume and as the mass of supplied ammonia- $\mathrm{N}$. The mass of bioavailable nitrogen was calculated as the sum of initial ammonium-N and urea$\mathrm{N}$ plus the mass of ammonia- $\mathrm{N}$ supplied till a given time: $m_{\mathrm{N}}(t)=V_{\mathrm{L}}\left(t_{0}\right) \cdot\left(C_{\mathrm{NH}_{4}-\mathrm{N}}\left(t_{0}\right)+\mathrm{C}_{\text {Urea-N }}\left(t_{0}\right)\right)+m_{\mathrm{NH}_{4} \mathrm{OH}-\mathrm{N}}(t)$. The consumed nitrogen is this $m_{\mathrm{N}}(t)$ value minus the nitrogen not yet used or lost by sampling: $\Delta m_{\mathrm{N}}(t)=m_{\mathrm{N}}(t)-V_{\mathrm{L}}(t) \cdot\left(C_{\mathrm{NH}_{4} \mathrm{~N}}(t)+C_{\text {Urea-N }}(t)\right)-$ $\Sigma m_{\mathrm{N}}$ (sampling). These $\Delta m_{\mathrm{N}}(t)$ values were used for calculating biomass-specific consumption rates $\left(r_{\mathrm{N}}\right.$ as $\left.\mathrm{mg}_{\mathrm{N}} / \mathrm{g}_{\mathrm{X}} / \mathrm{h}\right)$. The overall biomass yield for nitrogen $\left(Y_{\mathrm{X} / \mathrm{N}}\right)$ is the ratio between the mass of yeasts totally formed and the mass of $\mathrm{N}$ altogether consumed. The final $\mathrm{N}$ content of the biomass $\left(x_{\mathrm{N}}\right)$ is the reciprocal of this overall $Y_{\mathrm{X} / \mathrm{N}}$ value.

\section{Results and discussion}

\section{Nitrogen in non-supplemented DW medium}

The composition of whey depends on many factors such as origin of milk (cow, goat, or sheep), technology of curd production, and whey processing (e.g., [51,52]). Casein protein is coagulated by acidification (mineral or organic acids directly added or lactic acid produced in the processed milk by bacteria) and/or by using chymosin. Whey processing modifies the composition of whey as well: whey protein is separated by ultrafiltration, solutes are concentrated by reverse osmosis, and/ or minerals are partially removed by alkalinization. Preparation of whey-borne culture media also changes the composition by dilution, adding supplements, and heat sterilization. This explains why published compositions of whey-borne media highly fluctuate.

Several batches of non-supplemented DW medium were analyzed regarding potential sources of nitrogen and some other parameters (Table 1). The medium is rich in Isugar and thus exhibits a high potential for biomass growth. An amount of $78 \mathrm{~g} / \mathrm{L}$ sugar allows formation of $28 \mathrm{~g} / \mathrm{L} K$. marxianus biomass assuming $Y_{\mathrm{X} / \mathrm{S}}=$ $0.36 \mathrm{~g} / \mathrm{g}$ (as observed at aerobic cultivation in DW basic medium with trace elements [11]). These $28 \mathrm{~g} / \mathrm{L}$ biomass can only develop when yeast growth is not limited by 
Table 1 Composition of non-supplemented DW medium

\begin{tabular}{ll}
\hline Parameter & Value \\
\hline Sugars (88\% lactose, 12\% galactose) & $78 \mathrm{~g} / \mathrm{L}$ \\
Total N content (Kjeldahl analysis) & $403 \mathrm{mg} / \mathrm{L}$ \\
Ammonium-N & $106 \mathrm{mg} / \mathrm{L}$ \\
Urea-N & $43 \mathrm{mg} / \mathrm{L}$ \\
Nitrate-N & $4 \mathrm{mg} / \mathrm{L}$ \\
Nitrite-N & $<1 \mathrm{mg} / \mathrm{L}$ \\
Organic nitrogen (except urea-N) & $250 \mathrm{mg} / \mathrm{L}$ \\
Protein & \\
Sulfate-S $^{a}$ & $1,560 \mathrm{mg} / \mathrm{L}$ \\
Phosphate-P & $78 \mathrm{mg} / \mathrm{L}$ \\
Potassium & $410 \mathrm{mg} / \mathrm{L}$ \\
pH value & $2,600 \mathrm{mg} / \mathrm{L}$ \\
\hline
\end{tabular}

Concentrated and partially demineralized sweet whey permeate was diluted with the same volume of water and autoclaved for $15 \mathrm{~min}$ at $121^{\circ} \mathrm{C}$; precipitates were settled, and the upper clear phase was analyzed.

${ }^{a}$ According to the EC Nutrition Labelling Rules Directive 90/496/EEC, organic $\mathrm{N}$ multiplied by 6.25

any other resource than sugar. K. marxianus DSM 5422 grown under such conditions exhibited the following content of minerals (in milligrams of the addressed element per gram dry biomass): $x_{\mathrm{N}}=78 \ldots 79 \mathrm{mg} / \mathrm{g}[10,11], x_{\mathrm{P}}=$ $10 \mathrm{mg} / \mathrm{g}, x_{\mathrm{S}}=4 \mathrm{mg} / \mathrm{g}$, and $x_{\mathrm{K}}=2 \mathrm{mg} / \mathrm{g}$ (unpublished results). These data are similar to published compositions of K. marxianus [45,53-55] and Saccharomyces cerevisiae [40]. Multiplying these $x$ values with the cell concentration of $28 \mathrm{~g} / \mathrm{L}$ gives the required concentration of the respective element in the culture medium to allow non-limited growth: 2,200 mg/L N, $280 \mathrm{mg} / \mathrm{L} \mathrm{P,} 112 \mathrm{mg} / \mathrm{L} \mathrm{S}$, and $56 \mathrm{mg} / \mathrm{L} \mathrm{K}$. Nitrogen and sulfur are lacking in nonsupplemented DW medium while the phosphorous and potassium content covers the demand (Table 1).

DW medium owns $403 \mathrm{mg} / \mathrm{L}$ Kjeldahl-N (Table 1). Detailed analysis of five batches of non-supplemented DW medium gave 89 to $130 \mathrm{mg} / \mathrm{L}$ ammonium-N (106 mg/L on an average, $\left.\sigma_{\mathrm{n}-1}=15 \mathrm{mg} / \mathrm{L}\right), 38.4$ to $45.9 \mathrm{mg} / \mathrm{L}$ urea-N (43 mg/L on an average, $\sigma_{\mathrm{n}-1}=2.6 \mathrm{mg} / \mathrm{L}$ ), $4 \mathrm{mg} / \mathrm{L}$ nitrate$\mathrm{N}$, and $<1 \mathrm{mg} / \mathrm{L}$ nitrite-N. The Kjeldahl-N minus the urea$\mathrm{N}$ and inorganic $\mathrm{N}$ gives a proteinogenic $\mathrm{N}$ of $250 \mathrm{mg} / \mathrm{L}$ which corresponds to ca. $1.5 \mathrm{~g} / \mathrm{L}$ proteins (Table 1 ).

Utilization of whey proteins by $K$. marxianus is discussed controversially. Raw cheese whey owns 7 g/L protein comprising 50\% $\beta$-lactoglobulin, 20\% $\alpha$-lactalbumin, $15 \%$ glycomacropeptide, and $15 \%$ minor protein/peptide components [51]. Their microbial hydrolysis requires excretion of proteases. Decomposition of whey proteins by $K$. marxianus has been repeatedly studied; the results varied from absent hydrolysis [26], over $20 \%$ to $33 \%$ $[28,29,56]$, up to $80 \%$ hydrolysis [33]. Recent studies confirmed an extracellular serine protease for $K$. marxianus [57], and Yadav et al. [28] proved modification of whey proteins by $K$. marxianus via electrophoresis. Indigenous proteases in milk [58] and the proteolytic activity of lactobacilli [56] could also contribute some to protein modification during milk processing. Pre-treatment of whey protein with added proteases resulted in peptides $<1 \mathrm{kDa}$ which were efficiently assimilated by $K$. marxianus [59].

Some yeasts and fungi assimilate nitrate by intracellular reduction to ammonium [60]. K. marxianus seems to be unable for nitrate assimilation; at least several tested strains were negative [61]. This explains why nitrate added to whey did not improve growth of $K$. marxianus [32]. Some growth of $K$. marxianus in $\mathrm{NaNO}_{3}$-supplemented medium was possibly caused by the added yeast extract [62]. K. marxianus DSM 5422 proved to be unable to assimilate nitrate.

Due to the uncertainty of whey-protein assimilation by K. marxianus, it is assumed that whey proteins do not contribute to assimilable nitrogen. The utilizable nitrogen in non-supplemented DW medium of ca. $150 \mathrm{mg} / \mathrm{L}$ (ammonium-N plus urea-N) is thus much smaller than the calculated demand. Supplementation of DW medium with nitrogen is essentially required.

K. marxianus DSM 5422 grows well with ammonium $[10,11]$, but its growth with urea has not yet been tested. Yeasts generally assimilate urea [44] which should also apply to the studied strain.

A low amount of iron, zinc, and copper in DW medium limits growth of $K$. marxianus DSM 5422 [11]. Here, the medium was ever supplemented with trace-element solution to avoid such limitation.

\section{Test of several sources of nitrogen without previous $\mathrm{pH}$ adjustment}

This preliminary test for assimilation of diverse sources of nitrogen by $K$. marxianus DSM 5422 was performed in shake flasks. Non-supplemented DW medium was spiked with several $\mathrm{N}$ sources (Table 2): no supplement as a reference, $\left(\mathrm{NH}_{4}\right)_{2} \mathrm{SO}_{4}$ as the usual $\mathrm{N}$ supplement, $\left(\mathrm{NH}_{4}\right)_{2} \mathrm{CO}_{3}$ as an alternative ammonium resource, and urea as another $\mathrm{N}$ compound. The DW medium contributed ca. $7 \mathrm{mg} / \mathrm{L} \mathrm{N}$ ( $5 \mathrm{mg} / \mathrm{L} \mathrm{NH}_{4}-\mathrm{N}$ and $2 \mathrm{mg} / \mathrm{L}$ urea-N) to the assimilable $\mathrm{N}$ in each culture. The initial $\mathrm{pH}$ value was influenced by the added $\mathrm{N}$ source: $\left(\mathrm{NH}_{4}\right)_{2} \mathrm{SO}_{4}$ did not change the $\mathrm{pH}$ while urea and $\left(\mathrm{NH}_{4}\right)_{2} \mathrm{CO}_{3}$ alkalinized the medium (Table 2). All shake flasks were inoculated and pre-cultivated for $14 \mathrm{~h}$ before the process was followed by repeated OD and $\mathrm{pH}$ measurements (Figure 1).

The process without a supplement was at first similar to the process with $\left(\mathrm{NH}_{4}\right)_{2} \mathrm{SO}_{4}$ (Figure 1), but later, nitrogen became a limiting factor so that growth and medium acidification slowed down and nearly stopped after $24 \mathrm{~h}$. The $\mathrm{N}$-limited growth resulted in some residual sugar (Table 2). 
Table 2 Parameters at aerobic growth of K. marxianus DSM 5422 in media with various sources of nitrogen without previous pH adjustment

\begin{tabular}{|c|c|c|c|c|c|}
\hline \multirow[t]{2}{*}{ Parameter } & & \multicolumn{4}{|c|}{ Added source of nitrogen } \\
\hline & & No supplement & $\left(\mathrm{NH}_{4}\right)_{2} \mathrm{SO}_{4}$ & $\left(\mathrm{NH}_{4}\right)_{2} \mathrm{CO}_{3}$ & Urea \\
\hline Supplied N & {$[\mathrm{mg} / \mathrm{L}]$} & 0 & 106 & 146 & 117 \\
\hline $\mathrm{NH}_{4}-\mathrm{N}+$ urea- $\mathrm{N}$ & {$[\mathrm{mg} / \mathrm{L}]$} & 7 & 113 & 153 & 124 \\
\hline Initial pH value & {$[-]$} & 5.96 & 5.94 & 7.50 & 7.18 \\
\hline$\mu$ at $t=14 \mathrm{~h}$ & {$\left[h^{-1}\right]$} & 0.51 & 0.57 & 0.29 & 0.57 \\
\hline Final sugar & {$[\mathrm{g} / \mathrm{L}]$} & 0.92 & 0.00 & 0.15 & 0.00 \\
\hline Final biomass & {$[\mathrm{g} / \mathrm{L}]$} & 0.47 & 1.23 & 1.06 & 1.29 \\
\hline Final $\mathrm{pH}$ value & {$[-]$} & 3.99 & 2.47 & 3.45 & 7.10 \\
\hline
\end{tabular}

The whey and the sources of nitrogen were autoclaved together; the data belong to the experiment shown in Figure 1; the final parameters were measured after a total of $40 \mathrm{~h}$ of cultivation.

With a supplement of $\left(\mathrm{NH}_{4}\right)_{2} \mathrm{SO}_{4}$, K. marxianus DSM 5422 grew at first with $\mu=0.57 \mathrm{~h}^{-1}$ as usual in diluted DW medium $[12,14]$, but then, the growth slowed down due to medium acidification (Figure 1). A pH $<3.5 \mathrm{im}$ pairs growth of $K$. marxianus $[28,42,43]$. This acidification was caused by consumption of ammonium without an equivalent uptake of sulfate. The use of ammonium sulfate as an $\mathrm{N}$ source calls for buffered medium (in shake-flask experiments $[12,14]$ ) or for $\mathrm{pH}$ control (in bioreactor experiments $[10,11,13,16,22])$.

The supplement of $\left(\mathrm{NH}_{4}\right)_{2} \mathrm{CO}_{3}$ at first alkalinized the medium. The initial $\mathrm{pH}$ of 7.5 impacted growth of K. marxianus DSM 5422 and caused a highly retarded process (Figure 1). Vivier et al. [42] and Antoce et al. [43] found that a $\mathrm{pH}>7$ is adverse for growth of K. marxianus. Continued growth gradually reduced the $\mathrm{pH}$ and accelerated yeast growth so that all sugar had been consumed after $40 \mathrm{~h}$. Carbonate as an exchangeable anion can leave the medium in the form of carbon dioxide which counteracted acidification (medium with $\left.\left(\mathrm{NH}_{4}\right)_{2} \mathrm{CO}_{3}\right)$ while sulfate as a permanent ion remains and resulted in unfavorable acidification (medium with $\left.\left(\mathrm{NH}_{4}\right)_{2} \mathrm{SO}_{4}\right)$.

The supplement of urea also alkalinized the medium to some degree (initial $\mathrm{pH}=7.18$ ) which is, at the first view, surprising since urea reacts neutral in aqueous solution. Autoclaving the medium together with urea maybe caused some hydrolysis of urea to form alkaline ammonium carbonate. This slight alkalinization slowed down yeast growth and retarded the process a little at the beginning, but the yeast metabolism lowered the $\mathrm{pH}$ so that the growth rate approached a normal value during pre-cultivation (Table 2). After $21 \mathrm{~h}$, the medium acidification stopped and then the $\mathrm{pH}$ increased to a final $\mathrm{pH}$ of 7.1 (i.e., only temporary decrease in $\mathrm{pH})$. Absence of enduring $\mathrm{pH}$ changes confirms the earlier postulated proton neutrality at growth with urea $[38-40]$.
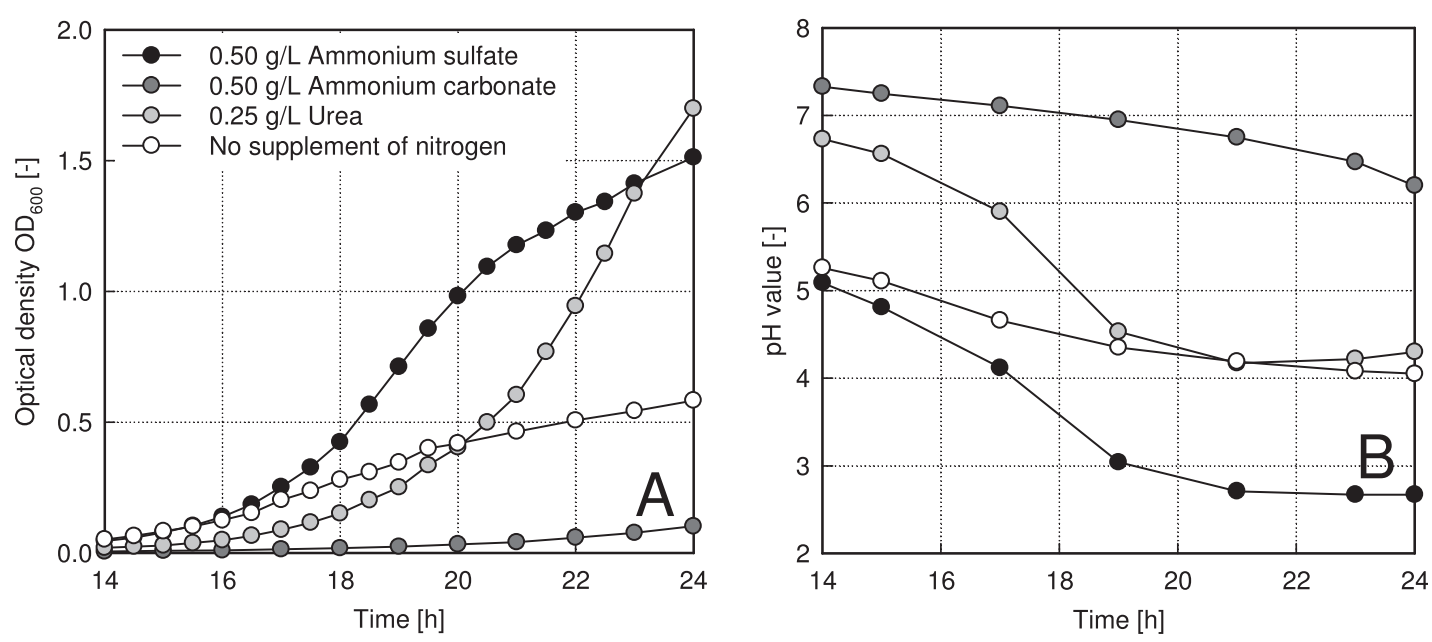

Figure 1 Aerobic batch cultivation of K. marxianus DSM 5422 without pH adjustment. Aerobic batch cultivation of K. marxianus DSM 5422 in media with various sources of nitrogen without previous $\mathrm{pH}$ adjustment. Concentrated and partially demineralized sweet whey was diluted with the same volume of water, supplemented with various sources of nitrogen, and autoclaved; the clear upper phase was supplemented with trace elements and diluted again with water resulting in media with $3.9 \mathrm{~g} / \mathrm{L}$ sugar; the media were inoculated and cultivated in conical flasks at $250 \mathrm{rpm}$ and $32^{\circ} \mathrm{C}$. 
Test of several sources of nitrogen with previous $\mathrm{pH}$ adjustment

The just-described shake-flask experiments were repeated with two modifications: all sources of nitrogen were autoclaved separately to eliminate unwanted interaction between the $\mathrm{N}$ sources and medium constituents, and the initial $\mathrm{pH}$ value was adjusted to 6.5 for avoiding alkaline conditions.

The convenient initial $\mathrm{pH}$ of 6.5 produced a uniformly high specific growth rate of $\mu=0.59 \mathrm{~h}^{-1}$ (Table 3) resulting in very similar cell densities at the beginning of the observation period (Figure 2A). This $\mu$ value was identical with the growth rate of $K$. marxianus DSM 5422 in highly diluted and phosphate-buffered DW basic medium $[12,14]$.

The culture without a supplement of nitrogen exhibited N-limited growth (Figure 2A), only moderate acidification owing to restricted growth (Figure 2B), a low biomass formation, and some residual sugar after $40 \mathrm{~h}$ of cultivation (Table 3). Supplementation with $\left(\mathrm{NH}_{4}\right)_{2} \mathrm{SO}_{4}$ or $\left(\mathrm{NH}_{4}\right)_{2} \mathrm{CO}_{3}$ resulted in a nearly identical growth behavior and similar final $\mathrm{pH}$ values and biomass yields (Table 2); the $\mathrm{pH}$ was suboptimal in both cases which caused impaired growth compared to the process in phosphate-buffered medium [12,14]. A reduced biomass yield for $K$. marxianus in whey at a low $\mathrm{pH}$ has also been described by Yadav et al. [28] and interpreted as diversion of lactose from anabolism (growth) toward catabolism (maintenance). The use of $\left(\mathrm{NH}_{4}\right)_{2} \mathrm{CO}_{3}$ instead of $\left(\mathrm{NH}_{4}\right)_{2} \mathrm{SO}_{4}$ was without advantage since the initial $\mathrm{pH}$ adjustment of $\left(\mathrm{NH}_{4}\right)_{2} \mathrm{CO}_{3}$-supplemented medium with hydrochloric acid caused substitution of exchangeable by permanent ions (carbonate replaced by chloride). $\left(\mathrm{NH}_{4}\right)_{2} \mathrm{CO}_{3}$ is thus not a useful alternative since a high initial $\mathrm{pH}$ inhibits yeast growth while preceding $\mathrm{pH}$ adjustment with acids eliminates the buffering effect of carbonate.

Separate autoclaving of the $\mathrm{N}$ source and initial $\mathrm{pH}$ adjustment caused good growth in the urea-supplemented medium from the beginning; then, the growth became somewhat retarded (at 18 to $22 \mathrm{~h}$; Figure 2A), but afterward, the growth accelerated again (at $t>22 \mathrm{~h}$ ) and even exceeded growth with $\left(\mathrm{NH}_{4}\right)_{2} \mathrm{SO}_{4}$ (Table 3). Quick growth in the first period was possibly based on whey-borne ammonium while the temporal slowdown of growth in the second period perhaps came about through the adaptation of yeast metabolism to urea assimilation after $\mathrm{NH}_{4}-\mathrm{N}$ depletion. The quite high biomass yield with urea is certainly attributed to an appropriate $\mathrm{pH}$ value over the whole growth period (compare $[39,62]$ ). Urea is thus a promising source of nitrogen for $K$. marxianus. The acidification with urea was only of temporal nature; the $\mathrm{pH}$ increased again to give a final value being nearly identical with the initial $\mathrm{pH}$ (due to proton neutrality at assimilation of urea [38-40]).

\section{Assimilation of urea by K. marxianus DSM 5422}

Ammonium is utilized by all common yeasts directly while urea is either hydrolyzed by urease to form ammonium or it is assimilated via the urea amydolyase pathway [25,38]. Urease acts extracellularly while the amydolyase pathway works intracellularly. $K$. marxianus is regarded as a urease-negative yeast [40] and should metabolize urea only in the latter way being a two-step process $[44,60,63]$; urea reacts with hydrocarbonate in an energy-consuming process to form allophanate which, in turn, is hydrolyzed to release ammonium:

$$
\begin{aligned}
& \begin{array}{l}
\mathrm{NH}_{2}-\mathrm{CO}-\mathrm{NH}_{2} \\
+\mathrm{HCO}_{3}^{-}+\mathrm{ATP}
\end{array} \rightarrow \begin{array}{l}
\mathrm{NH}_{2}-\mathrm{CO}-\mathrm{NH}-\mathrm{COO}^{-} \\
+\mathrm{H}_{2} \mathrm{O}+\mathrm{ADP}+\mathrm{P}_{\mathrm{i}}
\end{array} \\
& \begin{array}{l}
\mathrm{NH}_{2}-\mathrm{CO}-\mathrm{NH}-\mathrm{COO}^{-} \\
+3 \mathrm{H}_{2} \mathrm{O}+\mathrm{H}^{+}
\end{array} \rightarrow 2 \mathrm{NH}_{4}^{+}+2 \mathrm{HCO}_{3}^{-}
\end{aligned}
$$

These two reactions are catalyzed by urea carboxylase and allophanate hydrolase $[44,60,63]$. The produced ammonium is then metabolized in the same manner as ammonium taken up directly.

Table 3 Parameters at aerobic growth of $K$. marxianus DSM 5422 in media with various sources of nitrogen with initial

\begin{tabular}{|c|c|c|c|c|c|}
\hline \multirow[t]{2}{*}{ Parameter } & & \multicolumn{4}{|c|}{ Added source of nitrogen } \\
\hline & & No supplement & $\left(\mathrm{NH}_{4}\right)_{2} \mathrm{SO}_{4}$ & $\left(\mathrm{NH}_{4}\right)_{2} \mathrm{CO}_{3}$ & Urea \\
\hline Supplied N & {$[\mathrm{mg} / \mathrm{L}]$} & 0 & 106 & 146 & 117 \\
\hline $\mathrm{NH}_{4}-\mathrm{N}+$ urea- $\mathrm{N}$ & {$[\mathrm{mg} / \mathrm{L}]$} & 7 & 113 & 153 & 124 \\
\hline Initial $\mathrm{pH}$ value & {$[-]$} & 6.50 & 6.50 & 6.50 & 6.50 \\
\hline$\mu$ at $t=14 \mathrm{~h}$ & {$\left[h^{-1}\right]$} & 0.59 & 0.59 & 0.59 & 0.59 \\
\hline Final sugar & {$[g / L]$} & 1.03 & 0.00 & 0.00 & 0.00 \\
\hline Final biomass & {$[g / L]$} & 0.47 & 1.29 & 1.25 & 1.44 \\
\hline Final $\mathrm{pH}$ value & {$[-]$} & 4.29 & 2.43 & 2.54 & 6.45 \\
\hline
\end{tabular}
pH adjustment

The whey and the sources of nitrogen were autoclaved separately; the data belong to the experiment shown in Figure 2; the final parameters were measured after a total of $40 \mathrm{~h}$ of cultivation. 

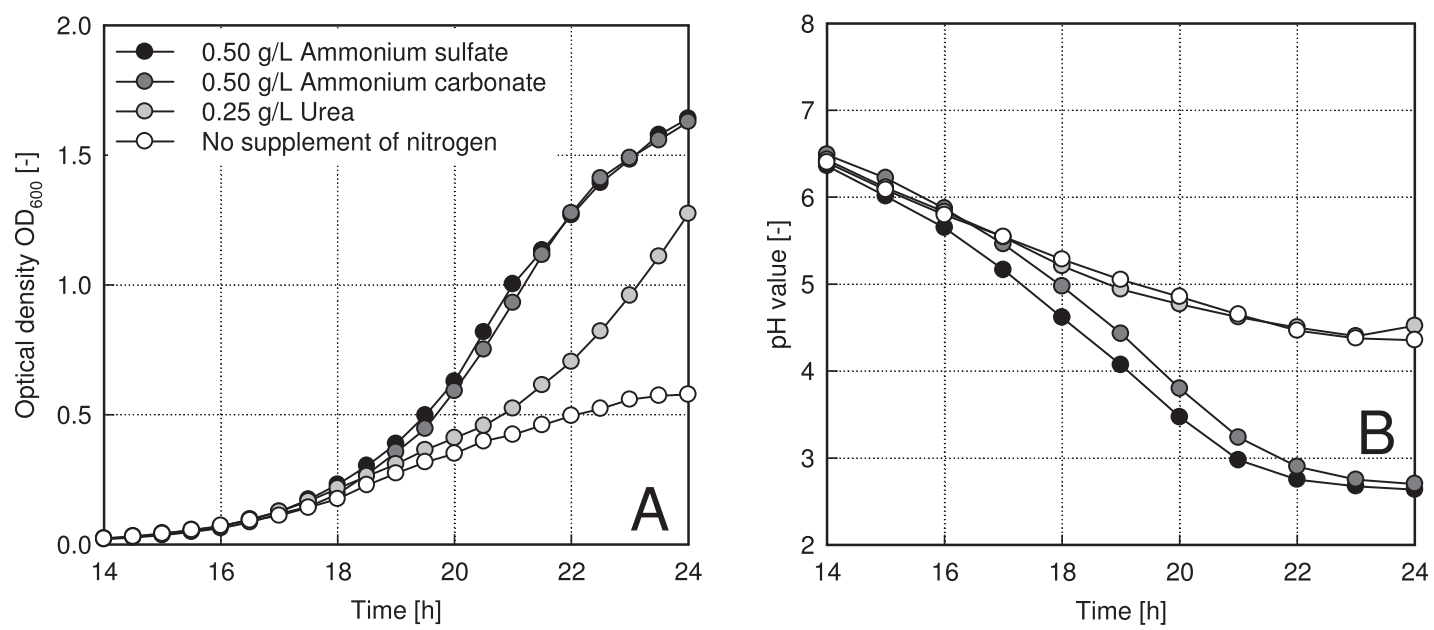

Figure 2 Aerobic batch cultivation of $K$. marxianus DSM $\mathbf{5 4 2 2}$ with initial pH adjustment. Aerobic batch cultivation of K. marxianus DSM 5422 in media with various sources of nitrogen with initial pH adjustment. Non-supplemented DW medium was supplemented with various sources of nitrogen and trace elements, the $\mathrm{pH}$ was adjusted to 6.5 by $\mathrm{HCl}$ or $\mathrm{KOH}$, and these media were diluted with water resulting in $3.9 \mathrm{~g} / \mathrm{L}$ sugar; the media were inoculated and cultivated in conical flasks at $250 \mathrm{rpm}$ and $32^{\circ} \mathrm{C}$.

An experiment was done for clarifying the way of urea assimilation in $K$. marxianus DSM 5422. The yeast was cultivated in diluted DW medium with urea, and the obtained culture was then used in an above-described test. K. marxianus DSM 5422 did not excrete urease into the medium since urea added to the cell-free aqueous fraction of this culture was not hydrolyzed at all. This is in accordance with Nahvi and Moeini [61] who found all tested $K$. marxianus and $K$. lactis strains being urease negative. These findings argue for assimilation of urea via the amydolyase pathway. The grown yeast biomass was incubated with urea in a phosphate buffer but only a bit urea was reacted to ammonium (average reaction rate $0.25 \mathrm{mg}$ urea $/ g_{X} / h$ ). Absent sugar obviously suppressed transfer of urea into ammonium which refers to an amydolyase pathway being under transcriptive control.

\section{Bioreactor cultivation with the addition of urea}

The shake-flask experiments clearly demonstrated the capability of $K$. marxianus DSM 5422 for urea assimilation. Urea is a promising source of nitrogen due to the proton neutrality at its consumption during yeast growth [38-40], avoiding strong acidification as happening at growth with $\left(\mathrm{NH}_{4}\right)_{2} \mathrm{SO}_{4}$. Urea has been repeatedly used at growth of $K$. marxianus, but the obtained results were inconsistent $[28,31,41,47,62]$. Hensing et al. [39] referred to the potential risk of an imbalance between release and assimilation of ammonium; the medium could alkalinize when ammonium is quicker released from urea than is incorporated into biomass. Such an alkalinization was observed during cultivation of K. marxianus in urea-supplemented whey [47]. In the abovedescribed experiments, the $\mathrm{pH}$ temporally decreased rather than increased. This phenomenon has not yet been understood and requires clarification in a bioreactor experiment.
K. marxianus DSM 5422 was cultivated in a stirred reactor at well-defined conditions $\left(32^{\circ} \mathrm{C}, \mathrm{pO}_{2} \geq 30 \%\right.$ air saturation, $\mathrm{pH} \geq 5$ ) in DW medium which was supplemented with urea, $\mathrm{Na}_{2} \mathrm{SO}_{4}$, and trace-element solution to avoid limitation of growth by nitrogen, sulfur or microelements. Another bioreactor experiment performed with DW medium containing $10 \mathrm{~g} / \mathrm{L}\left(\mathrm{NH}_{4}\right)_{2} \mathrm{SO}_{4}$ and trace elements was taken from [11] and used here as a reference. These two processes are depicted in Figure 3, and characteristic parameters are summarized in Table 4.

The courses of yeast growth, sugar consumption, and marginal ethanol formation were very similar for $\left(\mathrm{NH}_{4}\right)_{2} \mathrm{SO}_{4}$ or urea as the added $\mathrm{N}$ sources (Figure 3A). The only marked difference was the amount of formed biomass which was apparently higher with urea (Table 4). This observation is in accordance with Hensing et al. [39] and Rajoka et al. [62]. From the energetic point of view, growth with urea should be less effective compared to growth with ammonium since assimilation of urea via the amydolyase pathway requires ATP $[44,60,63]$. Cultivation with urea should therefore result in a lower rather than a higher biomass yield. In case of Hensing et al. [39] and Rajoka et al. [62], the observed low growth with ammonium was possibly caused by inhibitory acidification due to absent $\mathrm{pH}$ control at shake-flask cultivation. Such an inhibitory acidification was prevented by controlling the $\mathrm{pH}$ during bioreactor cultivation (Figure 3B); here, the diverging biomass yields were presumably caused by slightly different amounts of bioavailable nitrogen $(1.49 \mathrm{~g} \mathrm{~N}$ in medium with $5 \mathrm{~g} / \mathrm{L}$ urea, and $1.30 \mathrm{~g} \mathrm{~N}$ in medium with $\left.10 \mathrm{~g} / \mathrm{L}\left(\mathrm{NH}_{4}\right)_{2} \mathrm{SO}_{4}\right)$. Nearly all bioavailable nitrogen was assimilated in both processes (only 20 or $30 \mathrm{mg} / \mathrm{L}$ residual $\mathrm{NH}_{4}-\mathrm{N}$ in the culture broth; Table 4) which refers to a 

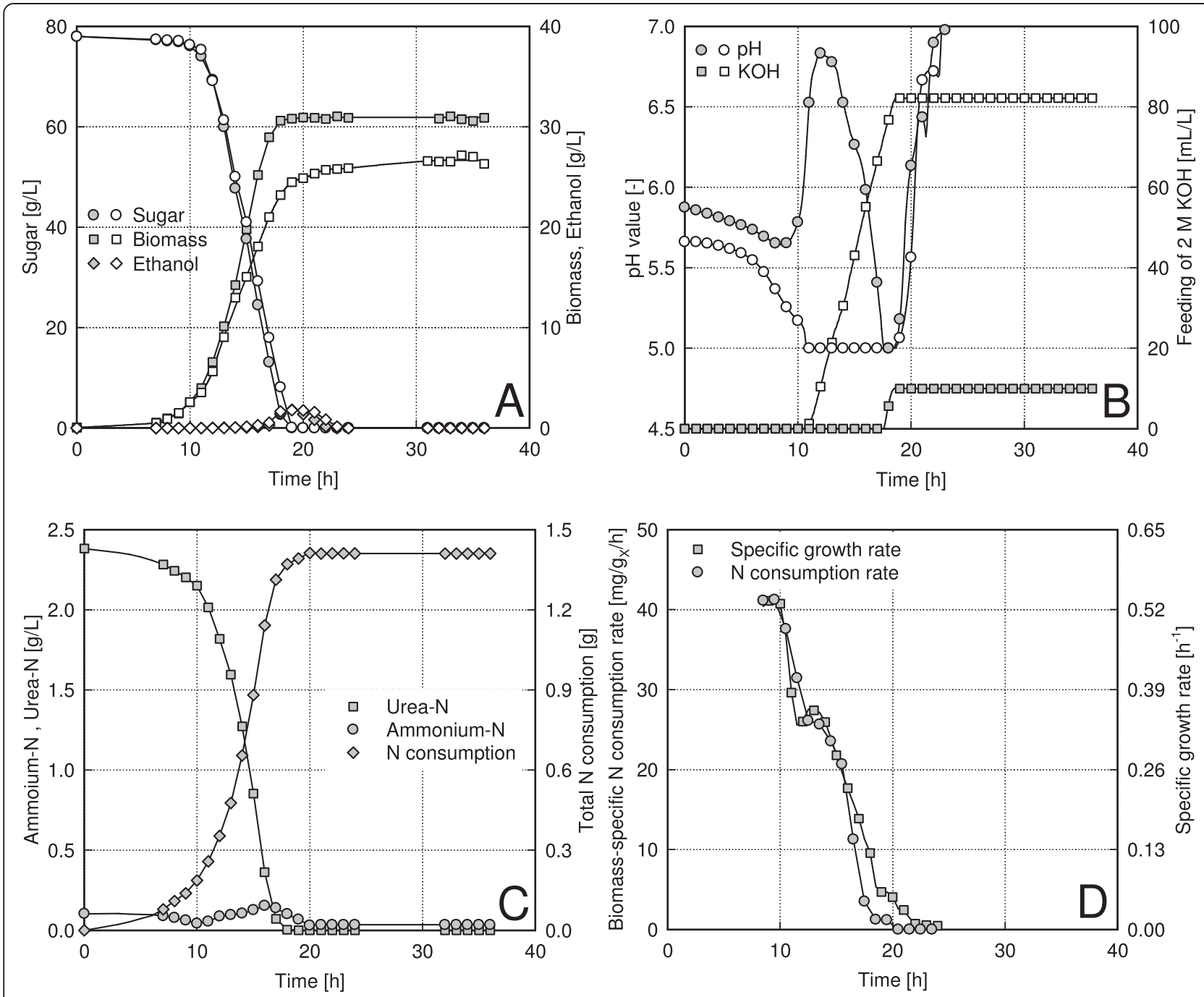

Figure 3 Aerobic batch cultivation of $K$. marxianus DSM 5422 in stirred bioreactors using ammonium or urea. Aerobic batch cultivation of $K$. marxianus DSM 5422 in a stirred bioreactor using ammonium (white symbols) or urea (grey symbols) as a source of nitrogen. DW medium

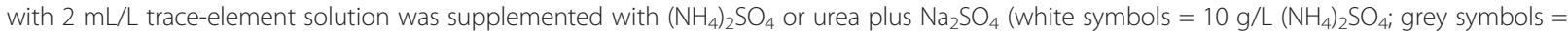
$5 \mathrm{~g} / \mathrm{L}$ urea and $0.4 \mathrm{~g} / \mathrm{L} \mathrm{Na}_{2} \mathrm{SO}_{4}$ ); the cultivation occurred in an $1-\mathrm{L}$ stirred reactor at 1,200 rpm, $32^{\circ} \mathrm{C}$, and aeration with $50 \mathrm{~L} / \mathrm{h}$; the $\mathrm{pH}$ was controlled to $\geq 5$ with $2 \mathrm{M} \mathrm{KOH}$; the given growth rate was derived from measured $\mathrm{CO}_{2}$ data.

slight deficit of nitrogen, and this deficit was more striking with $\left(\mathrm{NH}_{4}\right)_{2} \mathrm{SO}_{4}$. This argumentation is supported by a higher $\mathrm{N}$ content in the biomass grown with urea (Table 4).

In urea-supplemented medium, K. marxianus DSM 5422 grew at first quickly; but later, the growth slowed down more and more (Figure 3D), although sufficient $\mathrm{O}, \mathrm{N}, \mathrm{P}, \mathrm{S}, \mathrm{K}$, and trace elements should allow non-limited growth over an extended period. This behavior could be explained with a lack of vitamins in whey $[27,29]$ or with inhibition by whey-borne minerals [31]. Supplementing whey with yeast extract $[27,29]$ or vitamins $[29,32,47]$ stimulated the growth of $K$. marxianus.

The source of nitrogen distinctly influenced the $\mathrm{pH}(t)$ course (Figure 3B). With $\left(\mathrm{NH}_{4}\right)_{2} \mathrm{SO}_{4}$, the $\mathrm{pH}$ decreased due to ammonium consumption until the $\mathrm{pH}$ was controlled to $\mathrm{pH} 5 ; 82 \mathrm{~mL} / \mathrm{L} 2 \mathrm{M} \mathrm{KOH}$ were supplied which corresponds to a specific dosage of $0.34 \mathrm{~g} \mathrm{KOH}$ per $\mathrm{g}$ of produced biomass. The strong acidification with $\left(\mathrm{NH}_{4}\right)_{2} \mathrm{SO}_{4}$ is explained by a proton imbalance [38-40]: ammonium was consumed while most of the sulfate remained in the medium. With urea, the $\mathrm{pH}$ at first a little decreased, then sharply rose to $\mathrm{pH} 6.8$ and reduced again to $\mathrm{pH} 5$ where the $\mathrm{pH}$ controller avoided further acidification; the $\mathrm{KOH}$ dosage was in fact much smaller (only $10 \mathrm{~mL} / \mathrm{L} 2 \mathrm{M} \mathrm{KOH}$ or $0.04 \mathrm{~g} \mathrm{KOH}$ per $\mathrm{g}$ of produced biomass; Table 4). Hensing et al. [39] cultivated $K$. lactis in galactose medium with $\left(\mathrm{NH}_{4}\right)_{2} \mathrm{SO}_{4}$ or urea; the acidification was strong and permanent with $\left(\mathrm{NH}_{4}\right)_{2} \mathrm{SO}_{4}$, while the acidification was moderate and only temporary with urea.

During cultivation of $K$. marxianus DSM 5422 in ureasupplemented DW medium, the dissolved ammonium-N 
Table 4 Parameters at aerobic growth of $K$. marxianus DSM 5422 in media with various sources of nitrogen in a stirred bioreactor

\begin{tabular}{|c|c|c|c|c|c|c|}
\hline \multirow[t]{2}{*}{ Parameter } & & \multicolumn{5}{|c|}{ Added sources of nitrogen... } \\
\hline & & $\left(\mathrm{NH}_{4}\right)_{2} \mathrm{SO}_{4}{ }^{\mathrm{a}}$ & Urea & $\mathrm{NH}_{4} \mathrm{OH}$ & $\left(\mathrm{NH}_{4}\right)_{2} \mathrm{SO}_{4}+\mathrm{NH}_{4} \mathrm{OH}$ & $\left(\mathrm{NH}_{4}\right)_{2} \mathrm{SO}_{4}+\mathrm{NH}_{4} \mathrm{OH}$ \\
\hline Added $\left(\mathrm{NH}_{4}\right)_{2} \mathrm{SO}_{4}$ & {$[\mathrm{~g} / \mathrm{L}]$} & 10 & 0 & 0 & 1 & 2 \\
\hline Added urea & {$[g / L]$} & 0 & 5 & 0 & 0 & 0 \\
\hline Added $\mathrm{Na}_{2} \mathrm{SO}_{4}$ & {$[g / L]$} & 0 & 0.4 & 0.4 & 0 & 0 \\
\hline Initial $\mathrm{NH}_{4}-\mathrm{N}$ content & {$[g / L]$} & 2.12 & 0.10 & 0.13 & 0.30 & 0.53 \\
\hline Initial urea-N content & {$[g / L]$} & 0.04 & 2.38 & 0.04 & 0.04 & 0.04 \\
\hline Maximum growth rate & {$\left[h^{-1}\right]$} & 0.56 & 0.54 & 0.54 & 0.54 & 0.56 \\
\hline Consumed sugar & {$[\mathrm{g}]$} & 45.2 & 44.7 & 44.3 & 44.8 & 44.9 \\
\hline Final cell concentration & {$[\mathrm{g} / \mathrm{L}]$} & 26.7 & 30.8 & 7.49 & 22.1 & 27.0 \\
\hline Formed biomass & {$[\mathrm{g}]$} & 16.3 & 17.3 & 4.2 & 13.0 & 16.2 \\
\hline Overall $Y_{X / S}$ & {$[\mathrm{~g} / \mathrm{g}]$} & 0.362 & 0.388 & 0.095 & 0.289 & 0.361 \\
\hline Final $\mathrm{NH}_{4}-\mathrm{N}$ content & {$[\mathrm{g} / \mathrm{L}]$} & 0.02 & 0.03 & 0.00 & 0.04 & 0.17 \\
\hline Final urea- $\mathrm{N}$ content & {$[\mathrm{g} / \mathrm{L}]$} & 0.00 & 0.00 & 0.00 & 0.00 & 0.00 \\
\hline Supplied $2 \mathrm{M} \mathrm{NH}_{4} \mathrm{OH}$ & {$[\mathrm{mL}]$} & 0.0 & 0.0 & 0.0 & 24.8 & 39.8 \\
\hline Supplied ammonia-N & {$[\mathrm{g}]$} & 0.000 & 0.000 & 0.000 & 0.694 & 1.114 \\
\hline Consumed $\mathrm{NH}_{4}-\mathrm{N}$ & {$[\mathrm{g}]$} & 1.212 & 0.039 & 0.077 & 0.849 & 1.317 \\
\hline Consumed urea-N & {$[\mathrm{g}]$} & 0.024 & 1.371 & 0.025 & 0.026 & 0.023 \\
\hline Consumed N & {$[\mathrm{g}]$} & 1.236 & 1.410 & 0.102 & 0.875 & 1.340 \\
\hline Overall $Y_{X / N}$ & {$[\mathrm{~g} / \mathrm{g}]$} & 13.2 & 12.3 & 41.2 & 14.9 & 12.1 \\
\hline Final $N$ content, $x_{N}$ & {$[\mathrm{mg} / \mathrm{g}]$} & 76 & 81 & 24 & 67 & 83 \\
\hline Supplied $2 \mathrm{M} \mathrm{KOH}$ & {$[\mathrm{mL} / \mathrm{L}]$} & 82 & 10 & 0 & 0 & 0 \\
\hline Supplied KOH & {$\left[g_{\mathrm{KOH}} / g_{X}\right]$} & 0.34 & 0.04 & 0.00 & 0.00 & 0.00 \\
\hline Consumed oxygen & {$[\mathrm{g}]$} & 25.3 & 26.4 & 28.6 & 30.3 & 27.9 \\
\hline Formed $\mathrm{CO}_{2}$ & {$[g]$} & 35.1 & 37.2 & 41.2 & 42.5 & 39.0 \\
\hline Average RQ & {$[\mathrm{mol} / \mathrm{mol}]$} & 1.01 & 1.02 & 1.05 & 1.02 & 1.02 \\
\hline Maximum $C_{E t O H, L}$ & {$[\mathrm{~g} / \mathrm{L}]$} & 1.8 & 1.8 & $<0.1$ & 0.2 & $<0.1$ \\
\hline
\end{tabular}

Final parameters are valid for $36 \mathrm{~h}$ of cultivation with exception of the process with $\mathrm{NH}_{4} \mathrm{OH}$ as the only added $\mathrm{N}$ source where the final parameters were determined for $40 \mathrm{~h}$ of cultivation; cultivation at conditions as stated in Figures 3 and 4.

${ }^{a}$ Data in this column was in part taken from Urit et al. [10,11,14]; small deviations from the formerly published data are due to re-evaluation of basic data taking liquid sampling into account.

and urea- $\mathrm{N}$ were repeatedly measured and used for calculating the $\mathrm{N}$ consumption (Figure 3C). Intracellular conversion of urea to ammonium and usage of this ammonium for biomass growth occurred with nearly the same rate since ammonium excretion was only marginal (some $\mathrm{NH}_{4}-\mathrm{N}$ originated from the used whey). The $\mathrm{N}$ consumption correlated well with the yeast growth (compare Figure 3A and C) and, thus, the courses of the N consumption rate and the specific growth rate were similar (Figure 3D). The quotient of these rates represents a momentary $Y_{\mathrm{X} / \mathrm{N}}$ value.

The small transient $\mathrm{NH}_{4}-\mathrm{N}$ accumulation (Figure 3C) partially correlated with the temporary increase in $\mathrm{pH}$. Hensing et al. [39] already referred to the danger of alkalinization when ammonium release exceeds ammonium assimilation. Such an alkalization to $\mathrm{pH} 8.5$ was observed by Rech et al. [47] at cultivation of $K$. marxianus in urea- supplemented whey causing severe growth inhibition. Here, such an inhibition did not occur (only moderate rise of $\mathrm{pH}$ to 6.8).

\section{Bioreactor cultivation at a $\mathrm{pH}$-controlled feed of ammonia} Feeding the required nitrogen in form of ammonia could be a cost-saving alternative. Ammonia was repeatedly used as an $\mathrm{N}$ source at cultivation of $K$. marxianus in whey or other media [34,64-67] but dissolved ammonium or $\mathrm{N}$ consumption has not been paid much attention, with exception of Hack and Marchant [65] who depicted the time-dependent supply of ammonia.

In another series of bioreactor experiments, $K$. marxianus DSM 5422 was cultivated in DW medium as before but $2 \mathrm{M} \mathrm{NH}_{4} \mathrm{OH}$ was used as the predominating $\mathrm{N}$ source which was supplied by the $\mathrm{pH}$ controller at $\mathrm{pH}<5$. Three experiments were performed with a varied mass of 

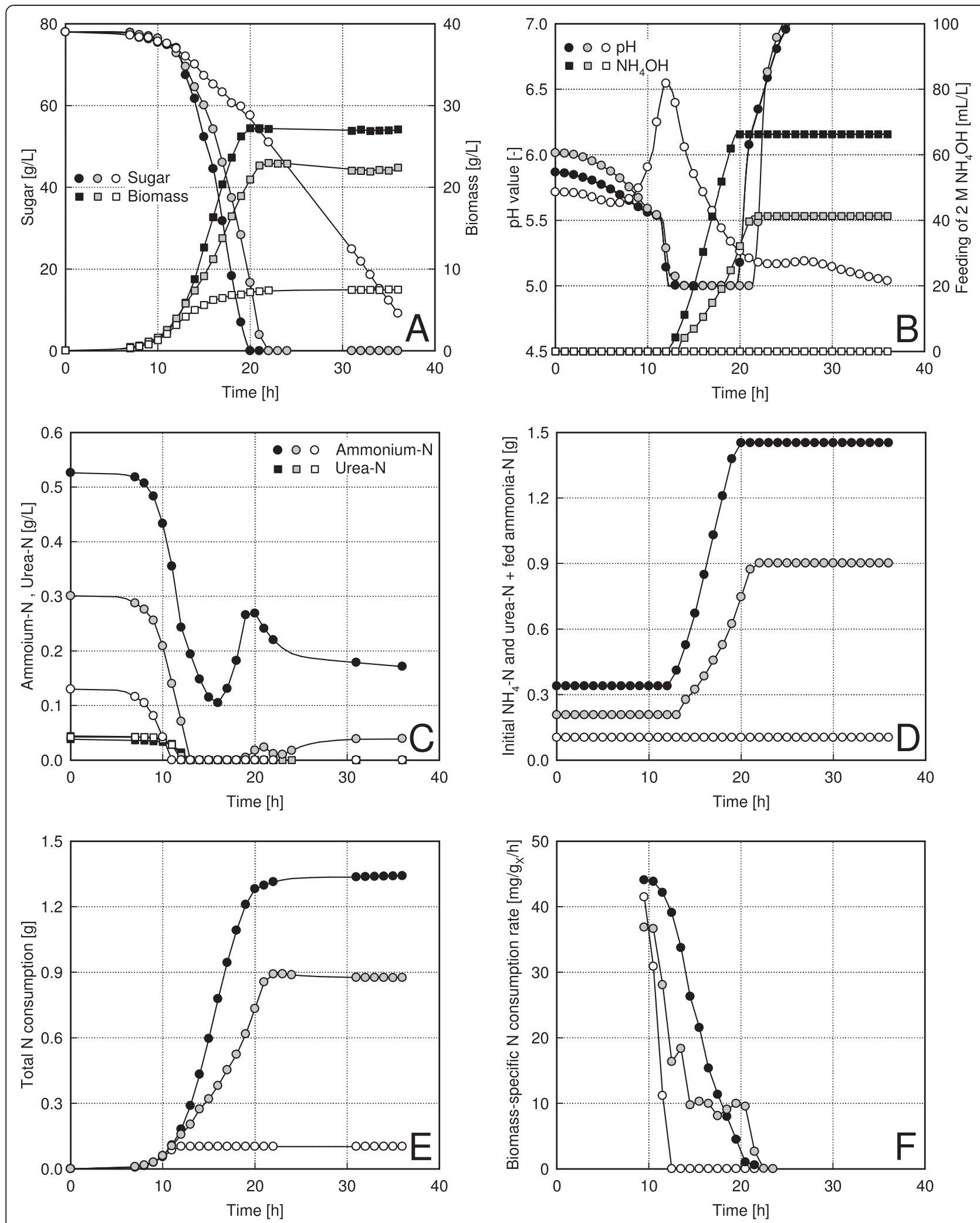

Figure 4 (See legend on next page.) 
(See figure on previous page.)

Figure 4 Aerobic batch cultivation of $K$. marxianus DSM 5422 in stirred bioreactors using $\left(\mathrm{NH}_{4}\right)_{2} \mathrm{SO}_{4}$ and $\mathrm{NH}_{4} \mathrm{OH}$. Aerobic batch cultivation of $K$. marxianus DSM 5422 in a stirred bioreactor using various amounts of $\left(\mathrm{NH}_{4}\right)_{2} \mathrm{SO}_{4}$ and $\mathrm{NH}_{4} \mathrm{OH}$ as sources of nitrogen. DW medium with $2 \mathrm{~mL} / \mathrm{L}$ trace-element solution was supplemented with $\left(\mathrm{NH}_{4}\right)_{2} \mathrm{SO}_{4}$ or $\mathrm{Na}_{2} \mathrm{SO}_{4}$ (white symbols $=0.4 \mathrm{~g} / \mathrm{L} \mathrm{Na} \mathrm{SO}_{4}$; grey symbols $=1 \mathrm{~g} / \mathrm{L}\left(\mathrm{NH}_{4}\right)_{2} \mathrm{SO}_{4}$; black symbols $\left.=2 \mathrm{~g} / \mathrm{L}\left(\mathrm{NH}_{4}\right)_{2} \mathrm{SO}_{4}\right)$; the cultivation occurred in an 1-L stirred reactor at 1,200 rpm, $32^{\circ} \mathrm{C}$, and aeration with $50 \mathrm{~L} / \mathrm{h}$; the pH was controlled to $\geq 5$ with $2 \mathrm{M} \mathrm{NH}_{4} \mathrm{OH}$; the given growth rates were derived from measured $\mathrm{CO}_{2}$ data.

$\left(\mathrm{NH}_{4}\right)_{2} \mathrm{SO}_{4}$ which was added as a pure substance to the autoclaved DW medium (0, 0.6, or $1.2 \mathrm{~g})$. These processes were limited neither by oxygen $\left(\mathrm{pO}_{2}\right.$ always $\left.>10 \%\right)$ nor by sulfur (proven by residual sulfate).

In DW medium without an $\left(\mathrm{NH}_{4}\right)_{2} \mathrm{SO}_{4}$ supplement (Figure 4; white symbols), $K$. marxianus DSM 5422 grew on whey-borne nitrogen $\left(0.13 \mathrm{~g} / \mathrm{L} \mathrm{NH}_{4}-\mathrm{N}\right.$ and $0.04 \mathrm{~g} / \mathrm{L}$ urea-N), but this nitrogen was quickly depleted (Figure $4 \mathrm{C}$ ) and the growth became $\mathrm{N}$ limited (Figure $4 \mathrm{~A}$ ). The $\mathrm{pH}$ temporally rose (Figure 4B) which seemingly correlated with urea consumption (Figure 4C). After depletion of all bioavailable $\mathrm{N}$, the $\mathrm{pH}$ decreased only slowly due to a low metabolic activity (look at the sugar concentration in Figure 4A). Later, the $\mathrm{pH}$ stagnated above $\mathrm{pH} 5$ and ammonia was thus not dosed (Figure 4B). The low availability of nitrogen (Figure 4D) caused restricted yeast growth (Figure 4A). The total $\mathrm{N}$ consumption and the $\mathrm{N}$ consumption rate were accordingly low (Figure 4E,F).

A supplement of $1 \mathrm{~g} / \mathrm{L}\left(\mathrm{NH}_{4}\right)_{2} \mathrm{SO}_{4}$ in the second experiment (Figure 4; grey symbols) increased the bioavailable $\mathrm{N}$ (Figure 4D) and allowed better yeast growth due to the higher initial $\mathrm{NH}_{4}-\mathrm{N}$ which let the $\mathrm{pH}$ quickly decrease (Figure 4B). After depletion of this nitrogen, the $\mathrm{pH}$ stagnated at 5.05 for a while and then dropped below 5 where the $\mathrm{pH}$ controller started dosage of ammonia (Figure 4B). The added ammonia was assimilated immediately, and no ammonium accumulated in the medium (Figure 4C). That is, the yeast growth continued but at $\mathrm{N}$-limited conditions as becoming visible from the low rates of ammonia dosage and $\mathrm{N}$ consumption (Figure 4D,F). This deficit of nitrogen slowed down growth and diminished the formed biomass (Figure 4A, Table 4). In the stationary period, some ammonium was released into the medium (Figure $4 \mathrm{C}$ ) which was also observed by Ghaly and Kamal [26] at the cultivation of $K$. marxianus in whey and interpreted as decomposition of yeast biomass with release of $\mathrm{NH}_{4}-\mathrm{N}$ into the medium.

A supplement of $2 \mathrm{~g} / \mathrm{L}\left(\mathrm{NH}_{4}\right)_{2} \mathrm{SO}_{4}$ in the third experiment (Figure 4; black symbols) increased the bioavailable $\mathrm{N}$ most (Figure 4D) and resulted in fast yeast growth and quick acidification. The feed of ammonia at $\mathrm{pH}<5$ started before the initially added $\mathrm{NH}_{4}-\mathrm{N}$ had been depleted (Figure 4C). The early start of ammonia dosage prevented limitation of yeast growth by nitrogen $\left(\mathrm{NH}_{4}-\mathrm{N}\right.$ always $>100 \mathrm{mg} / \mathrm{L}$ ), and the supply and uptake of nitrogen were well balanced (Figure 4C). The high rate of ammonia dosage corresponded with an accordingly fast growth and intensive $\mathrm{N}$ consumption (Figure 4D,E). The rate of $\mathrm{N}$ consumption became gradually smaller which is explained by the gently declining growth rate (possible reasons for this fading growth were discussed above). Urea was assimilated co-metabolically with the ammonium (Figure 4C).

The process with a supplement of $2 \mathrm{~g} / \mathrm{L}\left(\mathrm{NH}_{4}\right)_{2} \mathrm{SO}_{4}$ and ammonia dosage ran very similar to the process with $10 \mathrm{~g} / \mathrm{L}\left(\mathrm{NH}_{4}\right)_{2} \mathrm{SO}_{4}$; the final cell concentrations, formed biomasses, and the overall $Y_{\mathrm{X} / \mathrm{S}}$ values were nearly identical in both processes (Table 4) which demonstrates effective cultivation of $K$. marxianus with a $\mathrm{pH}$-controlled feed of ammonia. Supplementing the medium with some $\left(\mathrm{NH}_{4}\right)_{2} \mathrm{SO}_{4}$ was however required for a quick acidification and for initiation of ammonia dosage. The amount of added $\left(\mathrm{NH}_{4}\right)_{2} \mathrm{SO}_{4}$ could be reduced by changing the setpoint of the $\mathrm{pH}$ controller (e.g., to $\mathrm{pH}$ 5.5) so that dosage of ammonia starts earlier and avoids $\mathrm{N}$-limited conditions even at a reduced $\left(\mathrm{NH}_{4}\right)_{2} \mathrm{SO}_{4}$ supplement, but some $\left(\mathrm{NH}_{4}\right)_{2} \mathrm{SO}_{4}$ is needed to cover the requirement for sulfur.

\section{Nitrogen in biomass}

The content of nitrogen in biomass grown at cultivation in the stirred bioreactor (Figures 3 and 4 ) is the inverse of the overall biomass yield for nitrogen: $x_{\mathrm{N}}=1 / Y_{\mathrm{X} / \mathrm{N}}$. The overall $Y_{\mathrm{X} / \mathrm{N}}$ values were calculated from the produced biomass and the consumed nitrogen, assuming that only ammonium and urea were assimilated (Table 4). This calculation ignores that $K$. marxianus possibly hydrolyzes some whey-borne proteins and assimilates thus-formed peptides and amino acids. The $\mathrm{N}$ content of biomass depended on the extent of $\mathrm{N}$ limitation (Table 4): cultivation with enough nitrogen (process with $5 \mathrm{~g} / \mathrm{L}$ urea and process with $2 \mathrm{~g} / \mathrm{L}\left(\mathrm{NH}_{4}\right)_{2} \mathrm{SO}_{4}$ plus dosed ammonia) gave $x_{\mathrm{N}}$ values of 81 and $83 \mathrm{mg} / \mathrm{g}$, a slight deficit of nitrogen during the late growth stage (process with $10 \mathrm{~g} / \mathrm{L}$ $\left.\left(\mathrm{NH}_{4}\right)_{2} \mathrm{SO}_{4}\right)$ resulted in $x_{\mathrm{N}}=76 \mathrm{mg} / \mathrm{g}$, distinct $\mathrm{N}$ limitation (process with $1 \mathrm{~g} / \mathrm{L}\left(\mathrm{NH}_{4}\right)_{2} \mathrm{SO}_{4}$ plus ammonia) yielded $x_{\mathrm{N}}=67 \mathrm{mg} / \mathrm{g}$, while severe $\mathrm{N}$ limitation (process without any $\mathrm{N}$ supplement) produced an $x_{\mathrm{N}}$ value of only $24 \mathrm{mg} / \mathrm{g}$. A diminished $\mathrm{N}$ content of $K$. marxianus was also observed at limitation of growth by trace elements [10,11]. A decreased $\mathrm{N}$ content can be explained by a lowered portion of active biomass owing to intracellular storage of polysaccharides (details in $[10,11]$ ).

The $\mathrm{N}$ content can also be derived from the elemental composition of biomass. Several authors measured the cell composition for $K$. marxianus by elemental analyzers and transformed these data into biomass 
formulae: $\mathrm{CH}_{1.78} \mathrm{O}_{0.75} \mathrm{~N}_{0.16}$ [45], $\mathrm{CH}_{1.776} \mathrm{O}_{0.575} \mathrm{~N}_{0.159}$ [53], $\mathrm{CH}_{1.63} \mathrm{O}_{0.54} \mathrm{~N}_{0.16}$ [54], $\mathrm{CH}_{1.94} \mathrm{O}_{0.76} \mathrm{~N}_{0.17}$ [55]. These formulae represent an $\mathrm{N}$ content of $88,80,91$, or $83 \mathrm{mg} / \mathrm{g}$. The fluctuations originate from measuring errors and from a variable cell composition depending on growth conditions [68].

\section{Stoichiometry of yeast growth}

Stoichiometric equations for describing the growth of $K$. marxianus has been derived here by using the method of Hensing et al. [39] and Mazutti et al. [69]. Such balancing requires a sum formula for biomass. The above-given formulae for $\mathrm{K}$. marxianus biomass are restricted to $\mathrm{C}, \mathrm{H}$, $\mathrm{O}$, and $\mathrm{N}$ as the predominating elements (derived from elemental analyses [45,53-55]). Here, the elements P, S, and $\mathrm{K}$ are included for more precision. The $\mathrm{C}, \mathrm{H}$, and $\mathrm{O}$ content was taken from the above-given biomass formulae (as averages), the $\mathrm{N}$ content of $82 \mathrm{mg} / \mathrm{g}$ was taken from own measurements at non-limited yeast growth, and the $\mathrm{P}, \mathrm{S}$, and $\mathrm{K}$ content was assumed with 10,4 , and $2 \mathrm{mg} / \mathrm{g}$ (own assimilation measurements). Combination of these data gives $\mathrm{CH}_{1.78} \mathrm{O}_{0.66} \mathrm{~N}_{0.158} \mathrm{P}_{0.009} \mathrm{~S}_{0.0035} \mathrm{~K}_{0.0015}$ (yielding a molar mass of $27.027 \mathrm{~g} / \mathrm{mol}$ ).

Individual stoichiometric balance equations were derived for ammonium, urea, or ammonia as an $\mathrm{N}$ source, assuming respiratory growth (without formation of ethanol or ethyl acetate) of $K$. marxianus DSM 5422 with lactose as a substrate. The included stoichiometry coefficients were determined by balancing each element: seven balance equations were obtained containing nine unknown stoichiometric coefficients. This uncertain algebraic system was dissolved following Hensing et al. [39] by adding a proton balance and introducing the yield coefficient $\left(Y_{\mathrm{X} / \mathrm{S}}\right.$ informs about the relation of assimilatory to dissimilatory substrate utilization and allows to establish the mass ratio between formed biomass and consumed lactose). $Y_{\mathrm{X} / \mathrm{S}}=$ $0.36 \mathrm{~g} / \mathrm{g}$ was used here uniformly for all balances as found at non-limited growth with ammonium or ammonia (Table 4). Phosphate and sulfate were consumed in form of $\mathrm{HPO}_{4}{ }^{2-}$ and $\mathrm{SO}_{4}{ }^{2-}$ at the prevailing $\mathrm{pH}$. Three equations were obtained for ammonium, ammonium hydroxide, or urea as an $\mathrm{N}$ source:
Protons are only formed during growth with ammonium which explains the observed substantial consumption of $\mathrm{KOH}$ by the $\mathrm{pH}$ controller with ammonium sulfate; the proton release equates to $0.28 \mathrm{~g}$ consumed $\mathrm{KOH}$ per $\mathrm{g}$ grown biomass and hence somewhat deviates from the measured $\mathrm{KOH}$ consumption $\left(0.34 \mathrm{~g}_{\mathrm{KOH}} / \mathrm{g}_{\mathrm{X}}\right)$. With $\mathrm{NH}_{4} \mathrm{OH}$ or urea (Equations 4 and 5), the balances predict a slight alkalinization since $\mathrm{OH}^{-}$ions are formed. The consumption of some $\mathrm{KOH}$ with urea as an $\mathrm{N}$ source is contradictory to this finding, but it should be kept in mind that the final $\mathrm{pH}$ was higher than the initial $\mathrm{pH}$ (Figure 3B); synthesis of organic acids (acetate, pyruvate, 2-oxoglutarate, and succinate were by-products of aerobic sugar metabolism of $K$. marxianus $[16,68,70,71])$ presumably caused $\mathrm{KOH}$ consumption, and consumption of these acidic metabolites after depletion of sugar alkalinized the medium. But such temporary metabolite accumulation was not considered at balancing. Another interfering effect originates from whey-borne lactate (ca. $4 \mathrm{~g} / \mathrm{L}$ in DW medium [10]) whose microbial utilization also causes some alkalinization.

The balance equations allow to compare calculated with measured masses of consumed oxygen and formed carbon dioxide. The expected masses were calculated from the masses of utilized sugar. The measured masses (Table 4) were $1 \%$ to $20 \%$ smaller than predicted for unknown reason, but the ratio between formed $\mathrm{CO}_{2}$ and consumed oxygen (the average RQ values) was ca. $1.02 \mathrm{~mol} / \mathrm{mol}$ (Table 4$)$ and agreed well with the predicted values (1.01 to $1.03 \mathrm{~mol} / \mathrm{mol})$.

\section{Conclusions}

Whey is poor in nitrogen and requires supplementation with an $\mathrm{N}$ source for effective production of yeast biomass. Ammonium sulfate, as usually applied for this reason, causes medium acidification by residual sulfate which requires $\mathrm{pH}$ control by alkaline substances to avoid growth inhibition. Application of ammonium carbonate instead of ammonium sulfate is not helpful since added $\left(\mathrm{NH}_{4}\right)_{2} \mathrm{CO}_{3}$ elevates the $\mathrm{pH}$ to inhibitory levels. K. marxianus DSM 5422 assimilates urea as an
$\mathrm{C}_{12} \mathrm{H}_{22} \mathrm{O}_{11}+0.0410 \mathrm{HPO}_{4}^{2-}+0.0160 \mathrm{SO}_{4}^{2-}+0.0068 \mathrm{~K}^{+}+7.3790 \mathrm{O}_{2}+0.7205 \mathrm{NH}_{4}^{+} \rightarrow$
$4.5600 \mathrm{CH}_{1.78} \mathrm{O}_{0.66} \mathrm{~N}_{0.158} \mathrm{P}_{0.009} \mathrm{~S}_{0.0035} \mathrm{~K}_{0.0015}+7.4400 \mathrm{CO}_{2}+8.0963 \mathrm{H}_{2} \mathrm{O}+0.6133 \mathrm{H}^{+}$

$\mathrm{C}_{12} \mathrm{H}_{22} \mathrm{O}_{11}+\quad 0.0410 \mathrm{HPO}_{4}^{2-}+0.0160 \mathrm{SO}_{4}^{2-}+0.0068 \mathrm{~K}^{+}+7.3790 \mathrm{O}_{2}+0.7205 \mathrm{NH}_{4} \mathrm{OH} \rightarrow$
$4.5600 \mathrm{CH}_{1.78} \mathrm{O}_{0.66} \mathrm{~N}_{0.158} \mathrm{P}_{0.009} \mathrm{~S}_{0.0035} \mathrm{~K}_{0.0015}+7.4400 \mathrm{CO}_{2}+8.7095 \mathrm{H}_{2} \mathrm{O}+0.1072 \mathrm{OH}^{-}$

$\mathrm{C}_{12} \mathrm{H}_{22} \mathrm{O}_{11}+0.0410 \mathrm{HPO}_{4}^{2-}+0.0160 \mathrm{SO}_{4}^{2-}+0.0068 \mathrm{~K}^{+}+7.9189 \mathrm{O}_{2}+0.7205 \mathrm{NH}_{2} \mathrm{CONH}_{2} \rightarrow$ $4.5600 \mathrm{CH}_{1.78} \mathrm{O}_{0.66} \mathrm{~N}_{0.158} \mathrm{P}_{0.009} \mathrm{~S}_{0.0035} \mathrm{~K}_{0.0015}+8.1600 \mathrm{CO}_{2}+8.3495 \mathrm{H}_{2} \mathrm{O}+0.1072 \mathrm{OH}^{-}$ 
alternative $\mathrm{N}$ source. Consumption of urea means proton neutrality, medium acidification is minor, and only a little $\mathrm{pH}$ corrective is required. Moreover, the use of urea reduces the salt load (less inhibition, diminished environmental impact). Dosage of ammonia by the $\mathrm{pH}$ controller is a cost-saving alternative, but a suitable supplement of $\left(\mathrm{NH}_{4}\right)_{2} \mathrm{SO}_{4}$ is needed as a source of sulfur and for initiating dosage of ammonia.

\section{Competing interests}

The authors declare that they have no competing interests.

\section{Authors' contributions}

$\mathrm{CL}$ and $\mathrm{TU}$ conceived of the study. EG, CL, and TU explored relevant literature. $C L$ and $T U$ designed the experiments. EG and TU conducted the experiments. $\mathrm{CL}$ performed data analysis. $\mathrm{CL}$ and $\mathrm{TB}$ drafted the manuscript All authors read and approved the final manuscript.

\section{Acknowledgements}

Thanet Urit would like to express his thanks to the Nakhon Sawan Rajabhat University (Muang Nakhon Sawan, Thailand) for financial support. We are grateful to Mrs. E. Kneschke for technical assistance, to M. Heller from the Sachsenmilch Leppersdorf GmbH (Germany) for providing whey permeate, and to A. Stukert for performing two bioreactor experiments.

\section{Dedication}

This publication is dedicated to Prof. Dr. Andreas Zehnsdorf on the occasion of his 50 th birthday.

\section{Author details}

1 Institute of Food Technology and Bioprocess Engineering, TU Dresden 01062 Dresden, Germany. ${ }^{2}$ Department of Biology and Biotechnology, Faculty of Science and Technology, Nakhon Sawan Rajabhat University, 60000 Nakhon Sawan, Thailand.

Received: 27 June 2014 Accepted: 2 December 2014

Published online: 17 January 2015

\section{References}

1. Posada JA, Patel AD, Roes A, Blok K, Faaij APC, Patel MK (2013) Potential of bioethanol as a chemical building block for biorefineries: preliminary sustainability assessment of 12 bioethanol-based products. Bioresour Technol 135:490-499

2. Kim S-J, Jung S-M, Park Y-C, Park K (2007) Lipase catalyzed transesterification of soybean oil using ethyl acetate, an alternative acyl acceptor. Biotechnol Bioprocess Eng 12:441-445

3. Modi MK, Reddy JRC, Rao BVSK, Prasad RBN (2007) Lipase-mediated conversion of vegetable oils into biodiesel using ethyl acetate as acyl acceptor. Bioresour Technol 98:1260-1264

4. Uthoff S, Bröker D, Steinbüchel A (2009) Current state and perspectives of producing biodiesel-like compounds by biotechnology. Microb Biotechnol 2:551-565

5. Röttig A, Wenning L, Bröker D, Steinbüchel A (2010) Fatty acid alkyl esters: perspectives for production of alternative biofuels. Appl Microbiol Biotechnol 85:1713-1733

6. Hwang S-CJ, Lee C-M, Lee H-C, Pua HF (2003) Biofiltration of waste gases containing both ethyl acetate and toluene using different combinations of bacterial cultures. J Biotechnol 105:83-94

7. Kam S-K, Kang K-H, Lee M-G (2005) Removal characteristics of ethyl acetate and 2-butanol by a biofilter packed with jeju scoria. J Microbiol Biotechnol 15:977-983

8. Chan W-C, Su M-Q (2008) Biofiltration of ethyl acetate and amyl acetate using a composite bead biofilter. Bioresour Technol 99:8016-8021

9. Löser C, Urit T, Bley T (2014) Perspectives for the biotechnological production of ethyl acetate by yeasts. Appl Microbiol Biotechnol 98:5397-5415

10. Urit T, Löser C, Wunderlich M, Bley $T$ (2011) Formation of ethyl acetate by Kluyveromyces marxianus on whey: studies of the ester stripping. Bioprocess Biosyst Eng 34:547-559
11. Urit T, Löser C, Stukert A, Bley T (2012) Formation of ethyl acetate by Kluyveromyces marxianus on whey during aerobic batch cultivation at specific trace-element limitation. Appl Microbiol Biotechnol 96:1313-1323

12. Urit T, Manthey R, Bley T, Löser C (2013) Formation of ethyl acetate by Kluyveromyces marxianus on whey: influence of aeration and inhibition of yeast growth by ethyl acetate. Eng Life Sci 13:247-260

13. Löser C, Urit T, Stukert A, Bley T (2013) Formation of ethyl acetate from whey by Kluyveromyces marxianus on a pilot scale. J Biotechnol 163:17-23

14. Urit T, Li M, Bley T, Löser C (2013) Growth of Kluyveromyces marxianus and formation of ethyl acetate depending on temperature. Appl Microbiol Biotechnol 97:10359-10371

15. Löser C, Urit T, Nehl F, Bley T (2011) Screening of Kluyveromyces strains for the production of ethyl acetate: design and evaluation of a cultivation system. Eng Life Sci 11:369-381

16. Löser C, Urit T, Förster S, Stukert A, Bley T (2012) Formation of ethyl acetate by Kluyveromyces marxianus on whey during aerobic batch and chemostat cultivation at iron limitation. Appl Microbiol Biotechnol 96:685-696

17. Kallel-Mhiri H, Engasser J-M, Miclo A (1993) Continuous ethyl acetate production by Kluyveromyces fragilis on whey permeate. Appl Microbiol Biotechnol 40:201-205

18. Willetts A (1989) Ester formation from ethanol by Candida pseudotropicalis. Antonie Van Leeuwenhoek 56:175-180

19. Aziz S, Memon HUR, Shah FA, Rajoka MI, Soomro SA (2009) Production of ethanol by indigenous wild and mutant strain of thermotolerant Kluyveromyces marxianus under optimized fermentation conditions. Pak J Anal Environ Chem 10(1+2):25-33

20. Lertwattanasakul N, Rodrussamee N, Suprayogi LS, Thanonkeo P, Kosaka T, Yamada M (2011) Utilization capability of sucrose, raffinose and inulin and its less-sensitiveness to glucose repression in thermotolerant yeast Kluyveromyces marxianus DMKU 3-1042. AMB Express 1:20

21. Fonseca GG, de Carvalho NMB, Gompert AK (2013) Growth of the yeast Kluyveromyces marxianus CBS 6556 on different sugar combinations as sole carbon and energy source. Appl Microbiol Biotechnol 97:5055-5067

22. Löser C, Urit T, Keil P, Bley T (2014) Studies on the mechanism of synthesis of ethyl acetate in Kluyveromyces marxianus DSM 5422. Appl Microbiol Biotechnol. Accepted, doi:10.1007/s00253-014-6098-4

23. Armstrong DW, Yamazaki H (1984) Effect of iron and EDTA on ethyl acetate accumulation in Candida utilis. Biotechnol Lett 6:819-824

24. Fonseca GG, Heinzle E, Wittmann C, Gombert AK (2008) The yeast Kluyveromyces marxianus and its biotechnological potential. Appl Microbiol Biotechnol 79:339-354

25. Ugalde OU, Castrillo IJ (2002) Single cell proteins from fungi and yeasts. In: Dilip KA, George GK (eds) Applied mycology and biotechnology, vol 2, Agriculture and food production. Elsevier, Amsterdam, pp 123-149

26. Ghaly AE, Kamal MA (2004) Submerged yeast fermentation of acid cheese whey for protein production and pollution potential reduction. Water Res 38:631-644

27. Schultz N, Chang L, Hauck A, Reuss M, Syldatk C (2006) Microbial production of single-cell protein from deproteinized whey concentrates. Appl Microbiol Biotechnol 69:515-520

28. Yadav JSS, Bezawada J, Elharche S, Yan S, Tyagi RD, Surampalli RY (2014) Simultaneous single-cell protein production and COD removal with characterization of residual protein and intermediate metabolites during whey fermentation by K. marxianus. Bioprocess Biosyst Eng 37:1017-1029

29. Parrondo J, García LA, Díaz M (2009) Nutrient balance and metabolic analysis in a Kluyveromyces marxianus fermentation with lactose-added whey. Brazil J Chem Eng 26:445-456

30. De Nicola R, Hazelwood LA, De Hulster EAF, Walsh MC, Knijnenburg TA, Reinders MJT, Walker GM, Pronk JT, Daran J-M, Daran-Lapujade P (2007) Physiological and transcriptional responses of Saccharomyces cerevisiae to zinc limitation in chemostat cultures. Appl Environ Microbiol 73:7680-7692

31. Mahmoud MM, Kosikowski FV (1982) Alcohol and single cell protein production by Kluyveromyces in concentrated whey permeates with reduced ash. J Dairy Sci 65:2082-2087

32. Kar T, Misra AK (1998) Effect of fortification of concentrated whey on growth of Kluyveromyces sp. Rev Argent Microbiol 30(4):163-169

33. Belem MAF, Lee BH (1999) Fed-batch fermentation to produce oligonucleotides from Kluyveromyces marxianus grown on whey. Process Biochem 34:501-509

34. Domingues L, Lima N, Teixeira JA (2001) Alcohol production from cheese whey permeate using genetically modified flocculent yeast cells. Biotechnol Bioeng 72:507-514 
35. Moeini H, Nahvi I, Tavassoli M (2004) Improvement of SCP production and BOD removal of whey with mixed yeast culture. Electronic J Biotechnol 7:249-255

36. Aktaş N, Boyacı IH, Mutlu M, Tanyolaç A (2006) Optimization of lactose utilization in deproteinated whey by Kluyveromyces marxianus using response surface methodology (RSM). Bioresour Technol 97:2252-2259

37. Gupte AM, Nair AS (2010) $\beta$-galactosidase production and ethanol fermentation from whey using Kluyveromyces marxianus NCIM 3551. J Sci Ind Res 69:855-859

38. Castrillo Jl, de Miguel I, Ugalde UO (1995) Proton production and consumption pathways in yeast metabolism. A chemostat culture analysis. Yeast 11:1353-1365

39. Hensing MCM, Bangma KA, Raamsdonk LM, de Hulster E, van Dijken JP, Pronk JT (1995) Effects of cultivation conditions on the production of heterologous $\beta$-galactosidase by Kluyveromyces lactis. Appl Microbiol Biotechnol 43:58-64

40. Vicente A, Castrillo Jl, Teixeira JA, Ugalde U (1998) On-line estimation of biomass through $\mathrm{pH}$ control analysis in aerobic yeast fermentation systems. Biotechnol Bioeng 58:445-450

41. Tovar-Castro L, García-Garibay M, Saucedo-Castañeda G (2008) Lactase production by solid-state cultivation of Kluyveromyces marxianus CDBBL 278 on an inert support: effect of inoculum, buffer, and nitrogen source. Appl Biochem Biotechnol 151:610-617

42. Vivier D, Ratomahenina R, Moulin G, Galzy P (1993) Study of physicochemical factors limiting the growth of Kluyveromyces marxianus. J Ind Microbiol 11:157-161

43. Antoce O-A, Antoce V, Takahashi K (1997) Calorimetric study of yeast growth and its inhibition by added ethanol at various $\mathrm{pHs}$ and temperatures. Netsu Sokutei 24(4):206-213

44. Large PJ (1986) Degradation of organic nitrogen compounds by yeasts. Yeast 2:1-34

45. Castrillo II, Ugalde UO (1992) Energy metabolism of Kluyveromyces marxianus in deproteinated whey. Chemostat studies. Modelling. J Biotechnol 22:145-152

46. Castrillo Jl, Ugalde UO (1993) Patterns of energy metabolism and growth kinetics of Kluyveromyces marxianus in whey chemostat culture. Appl Microbiol Biotechnol 40:386-393

47. Rech R, Cassini CF, Secchi A, Ayub MAZ (1999) Utilization of protein-hydrolyzed cheese whey for production of $\beta$-galactosidase by Kluyveromyces marxianus. $J$ Ind Microbiol Biotechnol 23:91-96

48. Hortsch R, Löser C, Bley T (2008) A two-stage CSTR cascade for studying the effect of inhibitory and toxic substances in bioprocesses. Eng Life Sc 8:650-657

49. Rahmatullah M, Boyde TRC (1980) Improvements in the determination of urea using diacetyl monoxime; methods with and without deproteinisation. Clin Chim Acta 107:3-9

50. Francis PS (2006) The determination of urea in wine - a review. Aust J Grape Wine Res 12:97-106

51. Smithers GW (2008) Whey and whey proteins - from 'gutter-to-gold'. Int Dairy J 18:695-704

52. Prazeres AR, Carvalho F, Rivas J (2012) Cheese whey management: a review. J Environ Manage 110:48-68

53. Cordier J-L, Butsch BM, Birou B, von Stockar U (1987) The relationship between elemental composition and heat of combustion of microbial biomass. Appl Microbiol Biotechnol 25:305-312

54. Krzystek L, Ledakowicz S (2000) Stoichiometric analysis of Kluyveromyces fragilis growth on lactose. J Chem Technol Biotechnol 75:1110-1118

55. Silva-Santisteban BOY, Converti A, Filho FM (2006) Intrinsic activity of inulinase from Kluyveromyces marxianus ATCC 16045 and carbon and nitrogen balances. Food Technol Biotechnol 44:479-483

56. Hamme V, Sannier F, Piot J-M, Didelot S, Bordenave-Juchereau S (2009) Crude goat whey fermentation by Kluyveromyces marxianus and Lactobacillus rhamnosus: contribution to proteolysis and ACE inhibitory activity. J Dairy Res 76:152-157

57. Foukis A, Stergiou P-Y, Theodorou LG, Papagianni M, Papamichael EM (2012) Purification, kinetic characterization and properties of a novel thermo-tolerant extracellular protease from Kluyveromyces marxianus IFO 0288 with potential biotechnological interest. Bioresour Technol 123:214-220
58. Fox PF (2003) Significance of indigenous enzymes in milk and dairy products. In: Whitaker JR, Voragen AGJ, Wong DWS (eds) Handbook of food enzymology. Marcel Dekker Inc, New York, Basel, pp 255-277

59. Perea A, Ugalde U, Rodriguez I, Serra JL (1993) Preparation and characterization of whey protein hydrolysates: applications in industria whey bioconversion processes. Enzyme Microb Technol 15:418-423

60. Walker GM, White NA (2005) Introduction to fungal physiology. In: Kavanagh K (ed) Fungi: biology and applications. John Wiley \& Sons Ltd, Chichester, pp 1-34

61. Nahvi I, Moeini H (2004) Isolation and identification of yeast strains with high beta-galactosidase activity from dairy products. Biotechnol 3(1):35-40

62. Rajoka MI, Khan S, Latif F, Shahid R (2004) Influence of carbon and nitrogen sources and temperature on hyperproduction of a thermotolerant $\beta$-glucosidase from synthetic medium by Kluyveromyces marxianus. Appl Biochem Biotechnol 117(2):75-92

63. Whitney PA, Cooper TG (1972) Urea carboxylase and allophanate hydrolase. Two components of adenosine triphosphate: urea amido-lyase in Saccharomyces cerevisiae. J Biol Chem 247:1349-1353

64. Shay LK, Hunt HR, Wegner GH (1987) High-productivity fermentation process for cultivating industrial microorganisms. J Ind Microbiol 2:79-85

65. Hack CJ, Marchant R (1998) Characterisation of a novel thermotolerant yeast, Kluyveromyces marxianus var marxianus: development of an ethanol fermentation process. J Ind Microbiol Biotechnol 20:323-327

66. Nor ZM, Tamer MI, Scharer JM, Moo-Young M, Jervis EJ (2001) Automated fed-batch culture of Kluyveromyces fragilis based on a novel method for on-line estimation of cell specific growth rate. Biochem Eng J 9:221-231

67. Gélinas P, Barrette J (2007) Protein enrichment of potato processing waste through yeast fermentation. Bioresour Technol 98:1138-1143

68. Fonseca GG, Gombert AK, Heinzle E, Wittmann C (2007) Physiology of the yeast Kluyveromyces marxianus during batch and chemostat cultures with glucose as the sole carbon source. FEMS Yeast Res 7:422-435

69. Mazutti MA, Zabot G, Boni G, Skovronski A, de Oliveira D, Di Luccio M, Rodrigues MI, Maugeri F, Treichel H (2010) Mathematical modeling of Kluyveromyces marxianus growth in solid-state fermentation using a packed-bed bioreactor. J Ind Microbiol Biotechnol 37:391-400

70. Silva-Santisteban BOY, Converti A, Filho FM (2009) Effects of carbon and nitrogen sources and oxygenation on the production of inulinase by Kluyveromyces marxianus. Appl Biochem Biotechnol 152:249-261

71. Rocha SN, Abrahão-Neto J, Gombert AK (2011) Physiological diversity within the Kluyveromyces marxianus species. Antonie Van Leeuwenhoek 100:619-630

\section{Submit your manuscript to a SpringerOpen ${ }^{\odot}$ journal and benefit from:}

- Convenient online submission

- Rigorous peer review

- Immediate publication on acceptance

- Open access: articles freely available online

- High visibility within the field

- Retaining the copyright to your article

Submit your next manuscript at $>$ springeropen.com 